\title{
REVISION OF CYRTANDRA SECTION DISSIMILES (GESNERIACEAE)
}

\author{
GEMMA L.C. BRAMLEY \\ Royal Botanic Garden, 20A Inverleith Row, Edinburgh, EH3 5LR; \\ ICMB, Kings' Buildings, University of Edinburgh, Mayfield Road, Edinburgh, EH9 3JH. \\ Now at Royal Botanic Gardens Kew, Richmond, Surrey, TW9 3AB.
}

\section{SUMMARY}

Section Dissimiles C.B. Clarke is reviewed. Eleven species are known, one of which is newly described here $(C$. fulvisericea $)$, and one species is reduced to synonymy $(C$. producta $=C$. trisepala $)$. The section is centred on Borneo, with two outlying species in Sumatra and one in Peninsular Malaysia. Section Dissimiles is defined by a unique combination of characters, the most distinctive of these are: a zygomorphic calyx (the upper three lobes are fused to form one but the tips remain free, and the lower two lobes are completely separated to the base); anisophyllous leaf pairs, and a small (generally less than $2 \mathrm{~cm}$ long), predominantly white, somewhat translucent corolla.

Key words: Cyrtandra, section Dissimiles, Malesia, taxonomy.

\section{INTRODUCTION}

Cyrtandra J.R. Forst. \& G. Forst. is the largest genus in the Gesneriaceae, containing at least 600 species. It is distributed from the Nicobar Islands in the Indian Ocean to southern Thailand, throughout Malesia to the Philippines, Taiwan, southern Ryukyu Islands, south east to Queensland and the Loyalty Islands and east to the high islands of the Pacific to Hawaii. Centres of species richness and diversity appear to be Borneo, New Guinea and the Pacific Islands (Burtt, 2001).

Cyrtandra species usually grow as understorey shrubs, herbs, or rarely epiphytes in dense rain forest, often in ravines and gorges characterised by high humidity, very low light intensities and an almost constant moisture supply (Gillett, 1967). The genus forms a common element of the species-rich Indo-Malayan and Pacific Island rain forest, and is remarkable for its high capacity to produce local endemics.

In the last overall treatment of Cyrtandra, Clarke (1883) recognised 164 species, which he divided into 13 sections, and in doing so is the only botanist to attempt a sectional classification of the whole genus (Burtt, 2001). However, the species groups forming all the sections proposed in Clarke's treatment would not now be classified together (Burtt, 1990). Hence, Clarke's sections have been abandoned and currently there is no satisfactory infrageneric classification for the genus.

Other attempts at sectional classification have been based on Cyrtandra species from particular geographical areas: for example, Hillebrand (1888) proposed that the Hawaiian species could be assigned to five sections, to which St. John $(1966,1987)$ added a further two. Currently, the 53 Hawaiian Cyrtandra species are classified into 

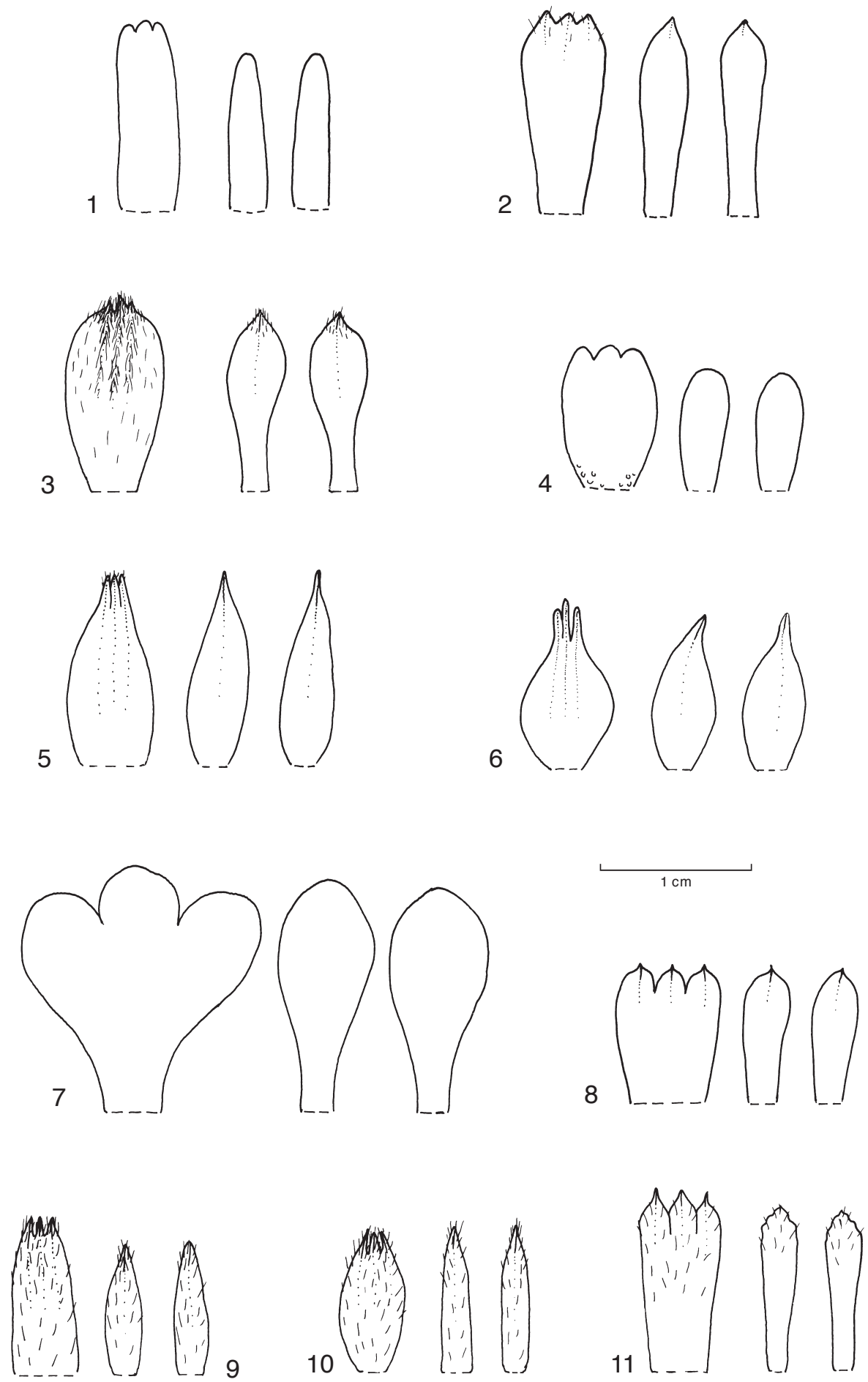
six sections, based on Hillebrand's (1888) original arrangement (Wagner et al., 1990, 1999).

In addition, Schlechter (1923) created 26 sections in his treatment of the genus in New Guinea. In West Malesia, Burtt (1990) has adopted some of Clarke's names for groups of species that are linked by distinct suites of morphological characters. In total, there are 40 validly published sectional names existing in Cyrtandra (Burtt, 2001). However, most species are not assigned to sections (e.g. Atkins \& Cronk, 2001; Burtt, 1970, 1978, 1990; Bramley \& Cronk, 2003; Bramley et al. 2004b). Recently, work has begun to describe individual sections, starting with Bornean species groups (e.g. Hilliard et al., 2003).

Section Dissimiles C.B. Clarke is one of the morphologically well-marked groups recognised by Burtt (1990). Molecular phylogenetic analyses (Bramley, 2003; Bramley et al. 2004a) suggest that the section can also be defined by molecular synapomorphies. Contrary to usual practice where a section is named after its type species such as section Decurrentes C.B. Clarke where $C$. decurrens is the type species, $C$. dissimilis C.B. Clarke was placed by Clarke (1883) in section Whitia (Blume) C.B. Clarke. Section Dissimiles therefore required lectotypification (Burtt, 1990). Burtt chose C. trisepala C.B. Clarke, as it was the only species to be illustrated in Clarke (1883) and clearly shows the characters defining the section. Clarke (1883) had also included a number of species that do not belong in the section, such as $C$. calycina Benth. (New Guinea), and $C$. incisa C.B. Clarke (Philippines), a decision perhaps understandable given the inadequate material he had to study.

There are eleven species recognised in this treatment of section Dissimiles; one species is new, and one species is reduced to synonymy. Section Dissimiles is centred on Borneo, with two outlying species in Sumatra (C. anisophylla C.B. Clarke and C. beccarii C.B. Clarke) and one in Peninsular Malaysia (C. stonei B.L. Burtt).

No single morphological character defines section Dissimiles, indeed many of the characters occur individually in other groups within the genus; it is a combination of characters that is unique to this group. The most distinctive characters are:

1) anisophylly - in most cases the leaves in a pair are not equal in size. One member of the pair develops fully, but the other remains small and stunted, often resembling a stipule. Very occasionally specimens are found with leaf pairs in which both members are more or less equal in size;

2) the calyx is zygomorphic: the upper three lobes are fused to form one but the tips remain free, and the lower two lobes are completely separated to the base. A typical Cyrtandra calyx is more regular, taking the form of a tube either with five more or less even lobes, or with three upper lobes that are shaped differently

Fig. 1. Dissected calyces of the 11 species of Cyrtandra section Dissimiles C.B. Clarke (all drawn to the same scale). For each species the outer surfaces of the fused upper lobe and the two completely divided lower lobes are illustrated. - 1. C.trisepala C.B. Clarke (Burtt \& Woods B2709); 2. C. multibracteata C.B. Clarke (Burtt \& Woods B2285); 3. C. fulvisericea Bramley (Clemens 32402); 4. C. anisophylla C.B. Clarke (Bünnemeijer 8554); 5. C. beccarii C. B. Clarke (De Wilde \& De WildeDuyfjes 13511); 6. C. stonei B.L. Burtt (Bramley et al. GB34); 7. C. weberi B.L. Burtt (Fuchs 21476); 8. C. impar Kraenzl. (Burtt \& Woods B2811); 9. C. rubropicta Kraenzl. (Burtt B12770); 10. C. iliasii B.L. Burtt (Burtt \& Martin B5012); 11. C. bryophila B.L. Burtt (Burtt B12880). 
from the two lower lobes. The calyx is also an important diagnostic character at the species level (Fig. 1);

3 ) the corolla is small (generally less than $2 \mathrm{~cm}$ long), predominantly white but sometimes with a greenish or pinkish tinge, quite fleshy and almost translucent or with translucent lines.

Other features common to the species within the section are not as diagnostic but collectively help to assign species to the section. The species all share a glandular hairy style, and they have a typical leaf venation pattern in which only the midrib and lateral nerve pairs are visible, and sometimes with a marginal vein. There is a strong tendency for the two upper corolla lobes to be shorter and with a much shallower division between them than the lower three lobes. The corolla wall often bulges outwards immediately behind the two upper lobes, resulting in an internal hollow in front of which the anthers lie. This hollow area is often filled with glandular hairs. The stamens have glandular hairs or glands on the filaments and connectives. The fruit is characteristically fleshier than it is in other western Malesian Cyrtandra species, where it is hard (sclerocarpous). Further characters define groups of allied species within the section, such as toothed leaf margins and flaky bark; these are discussed in the species notes.

\section{KEYS AND DESCRIPTIONS}

The following keys and descriptions present the 11 Cyrtandra species here recognised in section Dissimiles.

In the keys and descriptions:

1) Measurements are given for leaves presumed to be mature, and their shape is described following Hickey (1979). The larger member of a pair is referred to as the major leaf and the smaller one as the minor leaf.

2) All measurements of floral characters were taken from herbarium material that had been rehydrated and softened in spirit, or from spirit collections.

3) All details of plant heights and colours in the descriptions are taken from the collectors' notes on specimen labels.

4) All locations follow the American National Imagery and Mapping Agency's (NIMA) GEOnet Names Server (http://164.214.2.59/gns/html/index.html).

5) Cyrtandra flowers are protandrous, therefore flowers examined are either immature, in the male phase (the stamens dehiscing and gynoecium not at mature length), or in the female phase (the stamens having recoiled back into the corolla tube after dehiscence, and the gynoecium at full length) of development. Effort has been made to describe both male and female organs when mature, however, when this was not possible it is noted.

6) All specimens cited have been seen by the author unless stated otherwise.

CYRTANDRA J.R. Forst. \& G. Forst. (1775)

\section{Cyrtandra section Dissimiles}

Cyrtandra sect. Dissimiles C.B. Clarke (1883) 248. - Lectotype: Cyrtandra trisepala C.B. Clarke (Burtt, 1970). 
Terrestrial or epiphytic perennial herbs, shrubs or small trees. Leaves opposite, simple, petiolate; leaves in a pair most commonly anisophyllous (one member of a pair very reduced in size), very occasionally subequal, lamina hairy to glabrous above, below either glabrous or somewhat hairy with only the midrib and lateral nerve pairs visible and slightly raised, sometimes connected by a skirting marginal vein. Inflorescence in the upper leaf axils, sessile, subsessile or pedunculate; flowers few to many in pair-flowered cymes. Bracts ${ }^{1}$ often partly enclosing the inflorescence. Calyx persistent or caducous in fruit, zygomorphic, the upper three lobes fused to form one, divided into three tips, the lower two lobes separated to the base. Corolla 5-lobed, slightly bilabiate with the two upper lobes usually distinguishable from the three lower, usually white with a greenish or pinkish tint, the throat often marked with yellow, red, brown or purple, often with translucent lines. Fertile stamens 2. Staminodes 3, if present. Gynoecium ovary superior, hairy or glabrous; placentation parietal; stigma with two median lobes. Disk cupular. Fruit a somewhat fleshy berry, more or less globose to ovate or conical.

Distribution - Mainly Bornean, with two species in Sumatra and one in Peninsular Malaysia.

Etymology - The sectional name 'dissimiles' means dissimilar, unlike, and is most likely to be in reference to the anisophyllous leaf pairs.

\section{KEY TO THE SPECIES}

1a. Margins of the major leaf in a pair distinctly to shallowly serrate or dentate ... 2

b. Margins of the major leaf in a pair more or less entire . . . . . . . . . 7

2a. Bark tessellate or roughened with a tendency to become flaky near the tops of

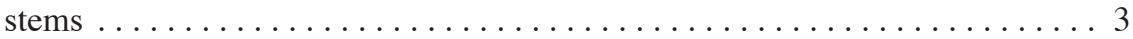

b. Bark smooth or striate or wrinkled in places. . . . . . . . . . . . 4

3a. Bark tessellate; outer surface of bracts glabrous; fused upper calyx lobe narrowly obovate, divided into three rounded tips; corolla white or cream with a yellow palate ....................... . impar

b. Bark roughened especially near the tops of stems; outer surface of bracts with short hairs; fused upper calyx lobe very narrowly ovate or narrowly elliptic, divided into three very narrowly triangular tips, thickened; corolla pink with red marks on the lower surface of the tube $\ldots \ldots \ldots \ldots \ldots \ldots \ldots \ldots$. C. rubropicta

4a. Lower surface of the major leaf in a pair glabrous $\ldots \ldots \ldots \ldots \ldots \ldots \ldots$

b. Lower surface of the major leaf in a pair with some hairs especially covering the

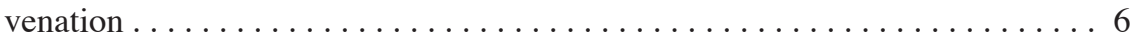

5a. Fused upper calyx lobe narrowly ovate, divided into three acuminate apical lobes, each one 1.5-2 mm long, thickened; bracts very narrowly to narrowly ovate, 1-2 $\mathrm{cm}$ long; major leaf in a pair $15-22$ by $5-7 \mathrm{~cm}$. - Peninsular Malaysia . . . . . . $\ldots \ldots \ldots \ldots \ldots \ldots \ldots \ldots \ldots \ldots \ldots \ldots \ldots \ldots \ldots \ldots \ldots \ldots \ldots$. stonei

b. Fused upper calyx lobe obovate, divided into three rounded apical lobes, each one c. $1 \mathrm{~mm}$ long, non-thickened; bracts broadly ovate, c. $1 \mathrm{~cm}$ long; major leaf in a pair $15-29$ by $6.5-12 \mathrm{~cm}$. - Sumatra . . . . . . . . 1. C. anisophylla

1) The term 'bracts' is used here for the first pair of bracteoles (prophylls) of the axillary cyme. In Cyrtandra these are usually more prominent than the subsequent bracteoles. 
6a. Fused upper calyx lobe broadly obovate, divided into three more or less semicircular tips, $3-5$ by $3-6 \mathrm{~mm}$, non-thickened and with no point at the very top; corolla up to $3 \mathrm{~cm}$ long; margins of major leaf serrate, serrations widely spaced, either quite shallow or up to $2 \mathrm{~mm}$ deep; lower leaf surface with a few rough hairs

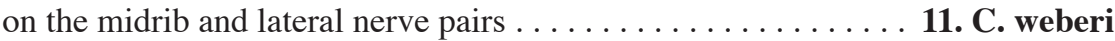

b. Fused upper calyx lobe obovate, divided into three triangular tips, c. $3 \mathrm{~mm}$ long, thickened with a c. $1 \mathrm{~mm}$ point at the very top; corolla c. $1.6 \mathrm{~cm}$ long; margins of major leaf with very shallow serrations in the upper half; lower leaf surface with dense rough hair on the midrib and lateral nerve pairs ..... 3. C. bryophila

7a. Lower surface of new leaves hairy to densely hairy; lower surface of mature leaves hairy, sometimes sparsely so $\ldots \ldots \ldots \ldots \ldots \ldots \ldots \ldots \ldots \ldots \ldots \ldots$

b. Lower surface of new leaves occasionally with some hairs but usually glabrous;

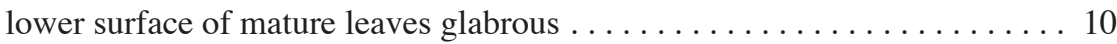

8a. Bark with a tendency to become flaky near the tops of the stems; larger leaf in a pair lorate, $13-17$ by $2-2.8 \mathrm{~cm} \ldots \ldots \ldots \ldots \ldots \ldots \ldots \ldots \ldots$. C. iliasii

b. Bark smooth or striate on all areas of the stem; larger leaf in a pair narrowly elliptic to very narrowly obovate, $10-28$ by $3-10 \mathrm{~cm} \ldots \ldots \ldots \ldots$

9a. Outer surface of calyx glabrous or with a few hairs at the tips; fused upper lobe of the calyx very narrowly to narrowly obovate, divided into three rounded tips, each c. $1 \mathrm{~mm}$, usually non-thickened; the minor leaf in a pair very narrowly ovate, the tip always erect. . . . . . . . trisepala

b. Outer surface of calyx with tufts of silky hair at the tips; fused upper lobe of the calyx elliptic, divided into three narrowly triangular tips, each 1-2 $\mathrm{mm}$ long, thickened; the minor leaf in a pair usually narrowly elliptic to very narrowly ovate, the upper third to half deflexed, or occasionally very narrowly ovate, the tip remaining erect $\ldots \ldots \ldots \ldots \ldots \ldots \ldots \ldots \ldots \ldots \ldots$. C. fulvisericea

10a. Inflorescence on peduncles $0.5-2 \mathrm{~cm}$; pedicels up to $4-10 \mathrm{~mm}$ long. - Sumatra 2. C. beccarii

b. Inflorescence on peduncles less than $0.5 \mathrm{~cm}$ long; pedicels $0.5-3 \mathrm{~mm}$. - Borneo

11a. The minor leaf in a pair sessile, never petiolate, not sheathing the stem, tip erect, never petiolate; bracts $1-1.3$ by $0.3-0.4 \mathrm{~cm}$, very narrowly ovate, chartaceous

10. C. trisepala

b. The minor leaf in a pair sessile or occasionally petiolate, partially or almost completely sheathing the stem, tip deflexed; bracts $1-3$ by $1-2 \mathrm{~cm}$, narrowly ovate to ovate, leathery . . . . . . . multibracteata

\section{Cyrtandra anisophylla C.B. Clarke - Map 1}

Cyrtandra anisophylla C.B. Clarke (1883) 249. - Type: Beccari s.n. (holo FI n.v.; iso K), Sumatra, W Sumatra, Mt Singgalang, 1700 m, 6 July 1878.

Erect shrub to $2 \mathrm{~m}$. Leaves markedly anisophyllous: major leaf with a c. $2 \mathrm{~cm}$ petiole, lamina elliptic to narrowly to very narrowly obovate, $15-29$ by $6.5-12 \mathrm{~cm}$, base asymmetric, one side up to $2 \mathrm{~cm}$ shorter and more acute than the longer one, margins serrate for the upper three quarters of the lamina, serrations quite widely spaced, apex obtuse to shortly acuminate, upper and lower surfaces glabrous, lateral nerve pairs 9-13, 
connected by a faint skirting vein c. $4 \mathrm{~mm}$ from the margin; minor leaf sessile, ovate, $1.5-3$ by $1-1.5 \mathrm{~cm}$, the basal part sheathing the stem, upper part deflexed, margins entire, apex acuminate, upper and lower surfaces glabrous. Inflorescence axillary, more or less sessile, with many flowers clustered together. Bracts broadly ovate, c. $1 \mathrm{~cm}$ long, green tinged brownish, overlapping and covering inflorescence, margins entire, outer surface somewhat verrucose at base, inner surface hairy. Bracteoles smaller, more numerous. Pedicels 2-3 mm long. Calyx fused upper lobe c. 9 by $6 \mathrm{~mm}$, obovate, divided into three rounded obtuse tips c. $1 \mathrm{~mm}$ long, lower lobes slightly shorter c. 8 by $3 \mathrm{~mm}$, apices rounded, outer surface glabrous, verrucose at base, inner surface with glandular and eglandular hairs. Corolla off-white, c. $8 \mathrm{~mm}$ long, completely enclosed by calyx (intact lobes not seen), outer surface with glandular hairs on the backs of the lobes, inner surface with short glandular hairs under the two upper lobes and in the throat. Filaments c. $4 \mathrm{~mm}$ long, with sessile glands. Anthers c. $1 \mathrm{~mm}$ long. Gynoecium c. $6 \mathrm{~mm}$ long, ovary glabrous except for a few short glandular hairs near the tip where it passes into the style, style with short glandular hairs. Disk c. $1.5 \mathrm{~mm}$ long, margin undulate. Fruit $5-10$ by $5-12 \mathrm{~mm}$, more or less globose, somewhat fleshy, verrucose, sometimes apiculate due to the persistent style.

Distribution - Sumatra (Aceh, N Sumatra, W Sumatra, Jambi (Kerinci)).

Habitat - Altitude 450-2000 m. Lowland to upper montane forest.

Etymology - The epithet 'anisophylla' means unequal leaves, referring to the anisophyllous leaf pairs.

Note - Cyrtandra anisophylla is a common and widespread species in Sumatra, occurring at a range of altitudes. It must not be confused with its closest ally C. bec-

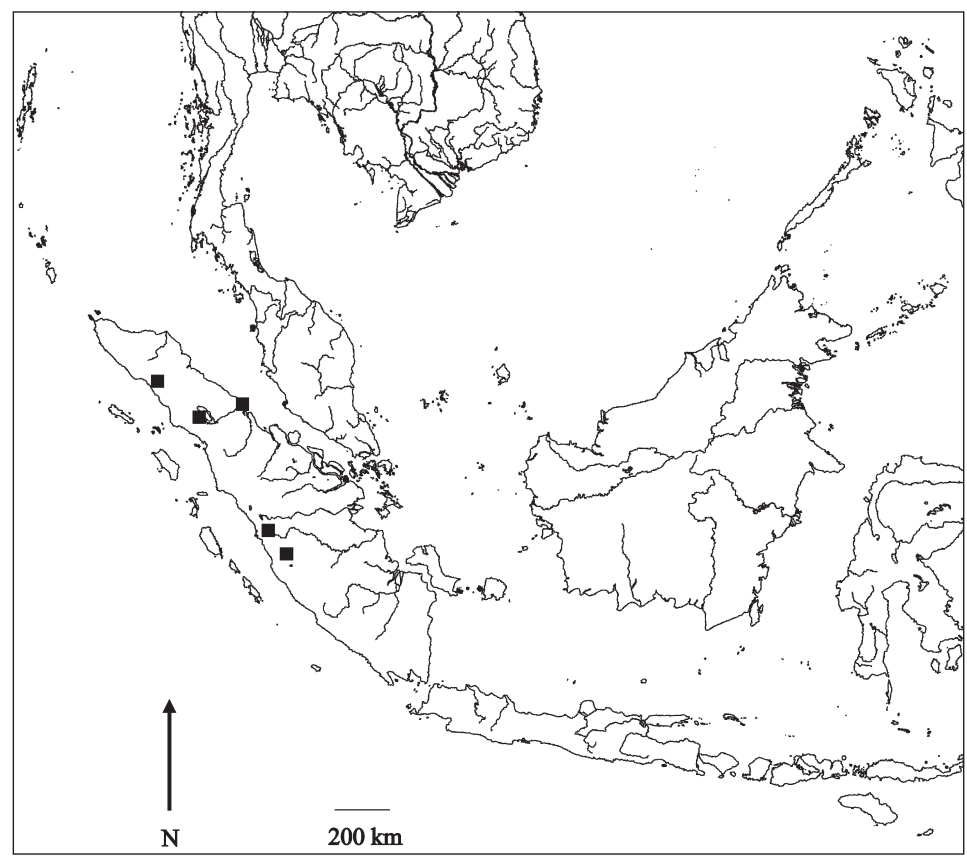

Map 1. Map of West Malesia showing the distribution of Cyrtandra anisophylla C.B. Clarke. 
carii, also from Sumatra, that has the same leaf type but bears a pedunculate rather than sessile inflorescence, and an upper calyx lobe with three narrowly triangular tips, different to the three rounded tips of $C$. anisophylla. A second allied species is $C$. stonei, apparently endemic to the Genting Highlands of Peninsular Malaysia. Cyrtandra stone $i$ has a sessile inflorescence like $C$. anisophylla, but an upper calyx lobe with three narrowly triangular tips, and narrowly to very narrowly ovate bracts like $C$. beccarii.

\section{Cyrtandra beccarii C.B. Clarke - Map 2}

Cyrtandra beccarii C.B. Clarke (1883) 249. - Type: Beccari 327 (holo FI n.v.; iso K, L), Sumatra, W Sumatra, Mt Singgalang, 1700 m, 6 July 1878.

Shrub to $3 \mathrm{~m}$, stem woody, bark glabrous. Leaves markedly anisophyllous: major leaf with a glabrous petiole 1-2 cm long, lamina narrowly elliptic or very narrowly obovate, $15-24$ by $4-8 \mathrm{~cm}$, base asymmetric, the shorter side narrower and more acute than the longer one, margins entire, apex shortly acuminate, both upper and lower surfaces glabrous, midrib raised below, lateral nerve pairs 10-12; minor leaf very shortly petiolate, tending to fall easily, lamina narrowly elliptic, $1-3$ by $0.4-1.2 \mathrm{~cm}$, margins entire, both upper and lower surfaces glabrous. Inflorescence axillary, pedunculate. Peduncles $0.5-2 \mathrm{~cm}$ long. Bracts narrowly to very narrowly ovate, c. 15 by $4-6 \mathrm{~mm}$, tips thickened, margins slightly undulate, outer surface with short hairs and a granular texture, inner surface with short hairs. Bracteoles shorter, surfaces as bracts. Pedicels up to $1 \mathrm{~cm}$ long. Calyx fused upper lobe c. 13 by $5 \mathrm{~mm}$, narrowly ovate, divided into three narrowly triangular tips, each c. $2 \mathrm{~mm}$ long, thickened along the median line and at the very top, this thickening extending down lobe as slightly raised ridges, lower lobes c. 13 by $2 \mathrm{~mm}$, very narrowly ovate, narrowing to a thickened point, this thickening extending down the centre of the lobes, outer surface glabrous except for a few short hairs near the tips, inner surface gland-dotted. Corolla white, c. $15 \mathrm{~mm}$ long, tube c. $11 \mathrm{~mm}$ long, upper lobes c. 3 by $2 \mathrm{~mm}$ with a $1 \mathrm{~mm}$ central sinus, lower lobes c. 4 by $3 \mathrm{~mm}$, outer surface with some short hairs on the back of the lobes, inner surface with glandular hairs on the roof of the tube underneath the two upper lobes, otherwise glabrous. Filaments with scattered glandular hairs, these also occurring on the connectives. Anthers c. $1.5 \mathrm{~mm}$ long. Gynoecium c. $1 \mathrm{~cm}$ long, ovary with some short glandular hairs near the tip, style with glandular hairs. Disk c. $2 \mathrm{~mm}$ long, margin undulate. Fruit $12-13$ by $6-11 \mathrm{~mm}$, ovate to subglobose.

Distribution - Sumatra (N Sumatra, W Sumatra).

Habitat - Altitude 1100-1850 m. Lower to upper montane forest.

Etymology - This species is named after Odoardo Beccari (1843-1920), the great Italian naturalist who eventually became director of the Florence Botanic Garden and Herbarium. He made many expeditions to SE Asia, and collected the type specimen of $C$. beccarii, and many other species that were described by Clarke (1883).

Note - Cyrtandra beccarii is one of two species of section Dissimiles present on Sumatra. Its closest ally is $C$. anisophylla, and the type collections are both from the same location, Mt Singgalang. It is easy to distinguish from $C$. anisophylla due to its pedunculate inflorescence and calyx morphology. Cyrtandra anisophylla has a subsessile inflorescence, the apex of the upper lobe of its calyx is divided into three rounded tips and the lower lobes also have rounded tips; the upper lobe of the calyx of C. bec- 


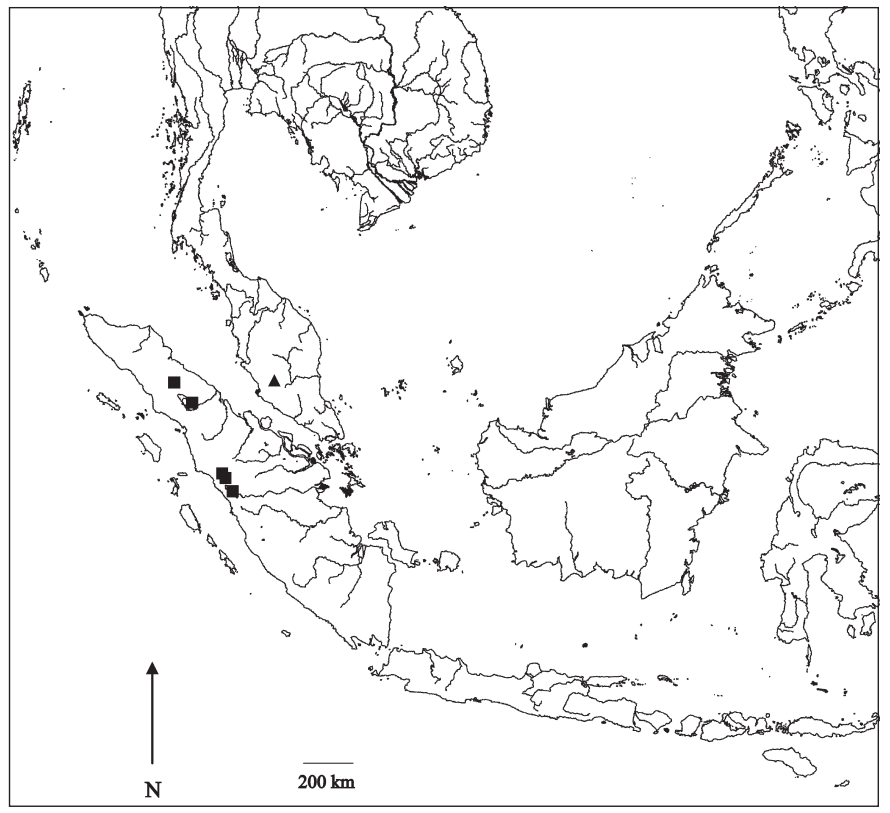

Map 2. Map of West Malesia showing the distribution of C. beccarii C.B. Clarke (ם); C. stonei B.L. Burtt ( $\mathbf{\Delta})$.

carii is divided at the apex into three narrowly triangular tips and the lower calyx lobes have pointed tips. Cyrtandra stonei, as yet known only from the Genting Highlands of Peninsular Malaysia is also a close ally, sharing its calyx and bract morphology with C. beccarii, but bearing a sessile rather than pedunculate inflorescence.

\section{Cyrtandra bryophila B.L. Burtt - Map 3}

Cyrtandra bryophila B.L. Burtt (1990) 209. - Type: Burtt B12880 (holo E), Sarawak, 7th Div., Kapit district, S Hose Mts, Camp VI, c. 1370 m [4500 ft], 13 April 1980.

Herb to $30 \mathrm{~cm}$, stem woody, bark slightly wrinkled in places, when young with rough hairs, in older growth these remaining to an extent around the axils. Leaves markedly anisophyllous: major leaf with a roughly hairy, often bryophyte covered, 1-1.5 $\mathrm{cm}$ petiole, lamina very narrowly obovate, rarely narrowly elliptic, $8-11$ by $2.8-4$ $\mathrm{cm}$, base slightly asymmetric, shorter side acute, longer side more rounded, margins shallowly serrate in the upper half, otherwise more or less entire, apex acuminate c. $1 \mathrm{~cm}$, upper surface glabrous with distinctive small raised bumps connected by wrinkles, often encrusted with bryophytes, lower surface bumpy, with short rough hairs, this longer and more dense on the raised midrib, lateral nerve pairs 8 or 9 , connected by a faint skirting vein c. $3 \mathrm{~mm}$ from the margin; minor leaf sessile, often caducous, c. 1 by $0.5 \mathrm{~cm}$, lower half sheathing the stem, the upper half deflexed, margins more or less entire, apex shortly acuminate, lower surface with rough hairs on the thickened midrib, upper surface glabrous. Inflorescence axillary, more or less sessile. Bracts 
narrowly ovate, $13-15$ by $6-7 \mathrm{~mm}$, margins undulate, outer surface warty, with hairs especially concentrated along the midrib, inner surface glabrous, gland-dotted, with a tuft of hair at the base. Bracteoles similar in size to bracts, surfaces as bracts. Pedicels c. $2 \mathrm{~mm}$ long. Calyx fused upper lobe c. 12 by $5 \mathrm{~mm}$, obovate, divided into three rounded triangular tips, each one c. $3 \mathrm{~mm}$ long, narrowing to a thickened point, c. $1 \mathrm{~mm}$ long, margins more or less entire, lower lobes c. 12 by $2 \mathrm{~mm}$, tips rounded but slightly thickened at the very top, distinctively hooked over, margins undulate; outer surface with hair concentrated on the tips and centre of the lobes, inner surface with scattered gland dots. Corolla white with a yellow palate, c. $16 \mathrm{~mm}$ long, tube c. $12 \mathrm{~mm}$ long, upper lobes c. 3 by $3 \mathrm{~mm}$ with a c. $1.5 \mathrm{~mm}$ central sinus, lower lobes c. 4 by $4 \mathrm{~mm}$, outer surface with hairs on the back of the lobes, inner surface glabrous apart from a patch of glandular hairs concentrated on the area between the two upper lobes, becoming more scattered near the lobe edges. Filaments with sessile glands in the upper half. Anthers 1-1.5 mm long. Gynoecium c. $9 \mathrm{~mm}$ long (immature), ovary glabrous, style with glandular hairs. Disk c. $1.5 \mathrm{~mm}$ long, margin more or less entire. Fruit (immature) c. 6 by $4 \mathrm{~mm}$, warty.

Distribution - Sarawak (Hose Mts).

Habitat - Altitude 1370-1447 m [4500-4750 ft]. Lower to upper montane forest, often in moss patches at the base of trees.

Etymology - The epithet 'bryophila' refers to this small plant's tendency to grow amongst, and become encrusted with, bryophytes.

Note - Cyrtandra bryophila is represented only by its type specimen. Its closest ally is probably $C$. impar, but it seems distinctive due to the wrinkled texture of

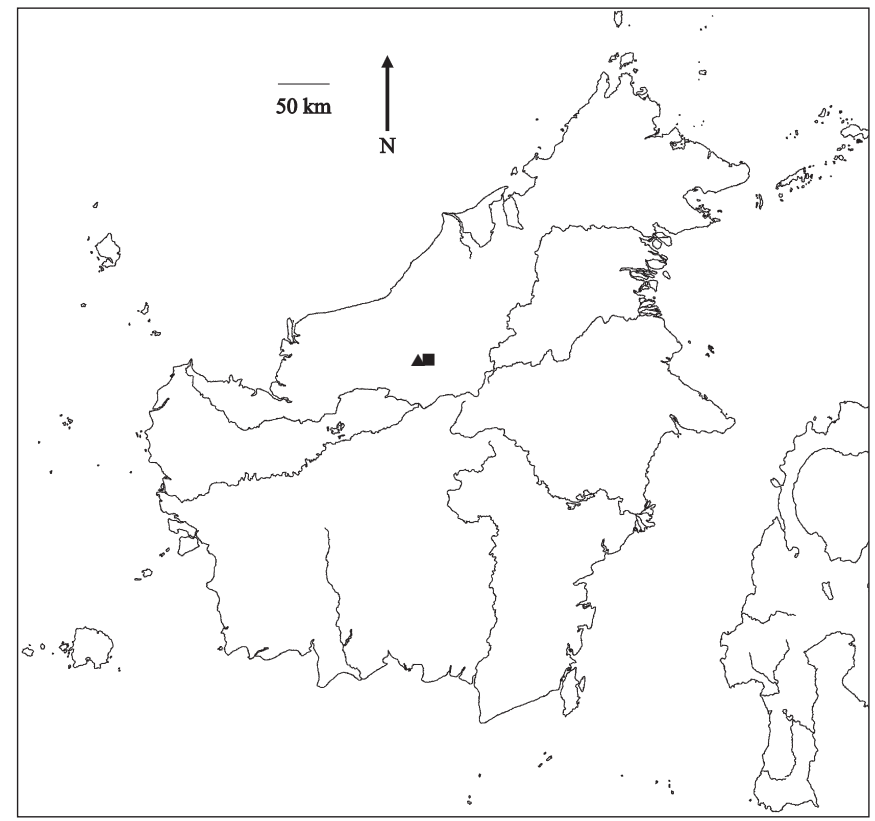

Map 3. Map of Borneo showing the distribution of C. bryophila B.L. Burtt ( $\mathbf{\square})$; C. iliasii B.L. Burtt $(\mathbf{\Lambda})$. 
its leaf surfaces, and in addition it differs from $C$. impar by its bracts, calyx and the outer surface of its corolla lobes, all of which are hairy rather than glabrous, and by its bark, which is smooth with slight wrinkles rather than tessellate. It is also close to C. rubropicta and C. iliasii, but can be distinguished by its different calyx shape (Fig. 1) and corolla coloration (white marked with yellow, rather than pink marked with red or white marked with orange and purple).

\section{Cyrtandra fulvisericea Bramley, spec. nov. - Fig. 2; Map 4}

C. multibracteatae et $C$. trisepalae affinis; differt a C. multibracteata foliis oblanceolatis vel angustis ellipticis, caulibus foliisque juvenilibus pilis fulvis sericeis tectis; differt a C. multibracteata et $C$. trisepala lobo supero elliptico calycis cum tribus apicibus incrassatis pilis fulvis sericeis (in C. multibracteata lobum superum ellipticum ad anguste obovatum calycis cum tribus apicibus incrassatis glabris vel sparsis pilis; in C. trisepala lobum superum angustum obovatum calycis cum tribus apicibus rotundis parce pilosis). - Typus: Clemens 32402 (holo BM; iso A, L), Sabah, Mt Kinabalu, Marai Parai Gigisan creek, $1370 \mathrm{~m}$ [4500 ft], 27 March 1933.

Shrub to $3 \mathrm{~m}$, stem woody, bark striate, when young usually clad with soft fulvous hairs, often densely so, the hairs thinning on older growth but remaining in the axils and usually on the petioles. Leaves in pairs, very occasionally more or less equal in size, but most often markedly anisophyllous; major leaf with an often densely hairy petiole $1-2 \mathrm{~cm}$ long, lamina narrowly elliptic or very narrowly obovate, $10-28$ by $3.5-10 \mathrm{~cm}$, base acute, sometimes asymmetrically so, the slightly shorter side more acute than the longer one, margins more or less entire, apex acuminate for $1-1.5 \mathrm{~cm}$, when young the lower surface very silky hairy, this hair thinning with age, older leaves bearing scattered hairs especially concentrated on the midrib and lateral nerves, texture minutely bumpy, upper surface more or less glabrous, lateral nerve pairs (6-)7-11(-12); minor leaf variable, sessile, most often the lamina upright, narrowly elliptic to very narrowly ovate, $1-3.5$ by $0.2-1 \mathrm{~cm}$, lower half to two thirds appressed to and partly sheathing the stem, upper part deflexed, base thickened around the midrib, margins entire, apex acuminate up to $1 \mathrm{~cm}$, lower surface with short hairs, warty especially around the base, upper surface glabrous apart from a tuft of hair at the base, slightly warty, or, rarely the lamina very narrowly ovate, $1-1.5$ by $0.4-0.6 \mathrm{~cm}$, midrib thickened especially towards the base, margins entire, apex erect, surfaces as other form. Inflorescence axillary, more or less sessile or very shortly pedunculate. Peduncles up to $3 \mathrm{~mm}$ long, stout. Bracts ovate, $1-2$ by $0.6-1 \mathrm{~cm}$, outer surface warty and hairy, especially along the midrib, inner surface with a tuft of long silky hair at the base. Bracteoles smaller and narrower, inner surface with a tuft of long silky hair at the base. Pedicels 2-3 mm long. Calyx fused upper lobe $9-12$ by $4-6 \mathrm{~mm}$, elliptic, divided into three thickened narrowly triangular tips, each $1-2 \mathrm{~mm}$ long, two lower lobes, $9-12$ by $1.5-3.5 \mathrm{~mm}$, narrowly elliptic to very narrowly ovate to very narrowly obovate; outer surface with tufts of silky hair at the tips, the hairs sometimes extending for $2 \mathrm{~mm}$, the rest of the lobe subglabrous or with scattered hairs, inner surface with glands and sometimes a tuft of silky hair at the base. Corolla white sometimes tinged with pale pink, with a yellow mark in the throat sometimes leading to a red or purple blotch, 14-18 $\mathrm{mm}$ long, tube 11-12 mm long, upper lobes $4-5$ by $3-5 \mathrm{~mm}$, with a $1-2 \mathrm{~mm}$ central sinus, lower lobes $3.5-6$ by $4-7 \mathrm{~mm}$, corolla wall bulging outwards immediately behind the lobes 


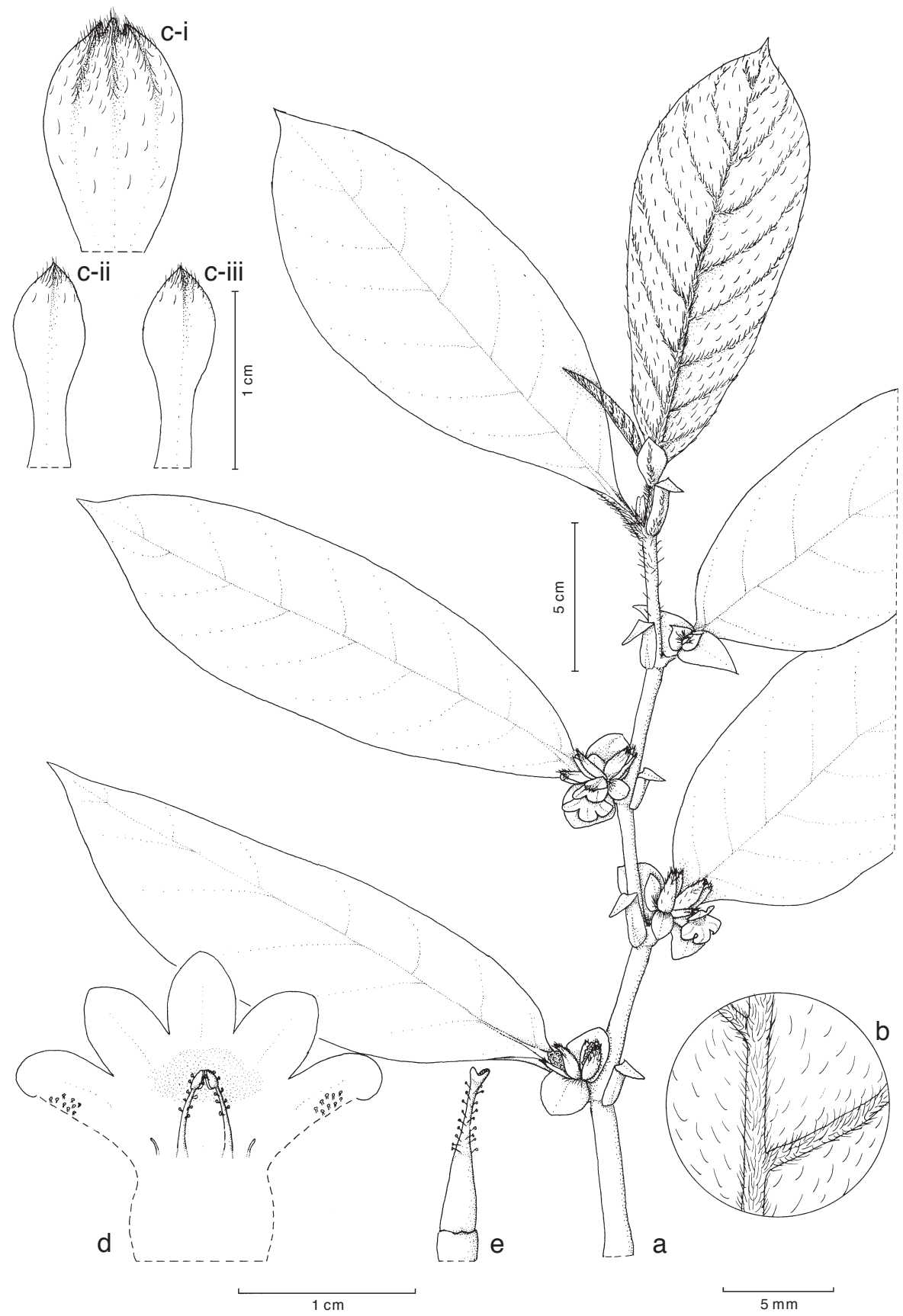

Fig. 2. Cyrtandra fulvisericea Bramley. a. Habit; b. detail of lower leaf surface; c-i. fused upper lobe of calyx, outer surface; c-ii. lower lobe of calyx, outer surface; c-iii. lower lobe of calyx, outer surface; d. corolla, dissected dorsally, showing stamens; e. gynoecium and disk. Drawn from Clemens 32402 (a-c), Mendum \& Lamb 27 (d, e). 
resulting in an internal hollow in front of which the anthers lie, outer surface with hairs on the back of the lobes, otherwise glabrous, inner surface glabrous except for a patch of glandular hairs within the pouch in the roof of the tube, occasionally the glandular hairs covering a larger area on either side of the pouch. Filaments 5-7 mm long, with some glandular hairs, these also occurring along the margins of the connective. Anthers c. $1.5 \mathrm{~mm}$ long. Gynoecium $0.8-1 \mathrm{~cm}$ long (immature), ovary glabrous, style with glandular hairs. Disk c. $1.5 \mathrm{~mm}$ long, margin undulate. Fruit $0.8-1.2$ by $0.3-0.5 \mathrm{~cm}$, conical, surface often markedly verrucose, calyx persistent in fruit.

Distribution - Brunei, Sabah, C Sarawak and the border with E Kalimantan.

Habitat - Altitude 100-3000 m. Lowland to upper montane forest, often on logs or rocks and boulders near streams or in the streambed.

Etymology - The epithet 'fulvisericea' refers to the fulvous silky hair that covers young growth, sometimes remaining on older growth, and is especially prevalent on the lower surface of the leaves, the stems and in the axils.

Note - Cyrtandra fulvisericea is characterised by the soft, silky fulvous hair that covers the young growth, often remaining on the lower surface of the leaves and in the axils, its hairy bracts, and the distinctive shape and indumentum of the upper lobe of its calyx. It is, however, variable in the major leaf shape and minor leaf morphology. It includes specimens that fall between $C$. trisepala and $C$. multibracteata, species that are, in their strict forms, easy to distinguish, but appear to have an intermediate group of specimens between them. This species is likely to require further study in the field, and more investigation into characters such as the shape of the minor leaf, the extent of the fulvous hairs, and the calyx morphology before the boundaries between its less distinctive forms and $C$. multibracteata and $C$. trisepala can be completely clarified.

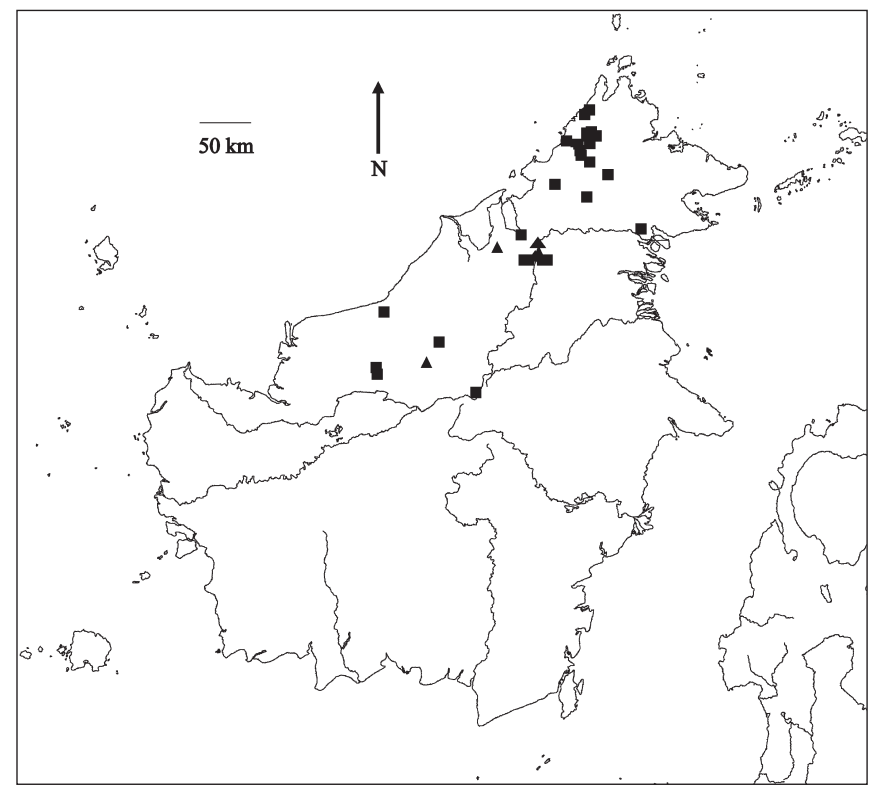

Map 4. Map of Borneo showing the distribution of $C$. fulvisericea Bramley: group one specimens $(\mathbf{\square})$; group two specimens $(\mathbf{\Delta})$. 
To assist future work and in order to highlight the variation within C. fulvisericea, collections are cited in informal groups:

Group one represents the typical C.fulvisericea: the young growth, axils, stems and petioles are clad with fulvous silky hair, and the minor leaf is usually deflexed in the upper third to half. The majority of the specimens originate from Sabah, especially Mt Kinabalu, but there are also representative collections from Sarawak, Brunei and East Kalimantan.

Group two includes specimens from around Gunung Mulu and Gunung Murud in the far east of Sarawak, and one specimen from the Hose Mts in Central Sarawak. These specimens are distinct because they retain more of the fulvous silky hairs on the lower surface of their mature leaves than group one, the parts of the inflorescence are generally more hairy, and the tip of the minor leaf remains erect (except Burtt B5074 where it is deflexed). The group two specimens are not, however, distinct in other characters, the calyx morphology in particular being extremely similar to that of group one specimens, so the features by which they at first seem distinct must be considered to be part of the variation within $C$. fulvisericea.

Selected collections:

Group one - SABAH. Beaman \& Beaman 7005 (E, L), Crocker range, km 4.25 on Kota Kinabalu - Tambunan Rd, 1220 m, 17 Sept. 1983; Carr SFN27589 (SING), Mt Kinabalu N.P., Kadamaian River, 1830 m [6000 ft], 12 June 1933; Chew et al. RSNB1431(E, K), Mt Kinabalu N.P., Ulu Ligwagu \& Ulu Mesilau, 1220 m [4000 ft], 3 Sept. 1961; Clemens 26061 (BM, L, SING), Mt Kinabalu N.P., Dallas, 11 Aug. 1931; Clemens 28810 (A, BM, L, SING), Mt Kinabalu N.P., Tenompok, 1675 m [5500 ft], 11 March 1932; Jimpin SAN125568 (K, KEP), Gunung Trusmadi, Tambunan, 22 Aug. 1988; Mendum \& Lamb 14 (E), Gunong Alab, 1650 m, 3 Aug. 1998; Stevens et al. 610 (A, E, KEP, L), Mt Kinabalu N.P., Ranau, Boundary Rentis, 1554 m, 22 Jan. 1976. - SARAWAK. Anderson \& Ilias Paie S28677 (E), summit ridge of Bukit Tibang on Indonesian border, headwaters of Balleh river, Kapit District, 1525 m [5000 ft], 12 July 1969; Ashton S19157 (E), Bukit Mersing, 1100 m, 5 Oct. 1963; Chai S36019 (E, K, KEP, L), Ulu Sungei Kapit, 110 m, 25 Feb. 1975; Ilias Paie S28447 (E, K, L), Bukit Batu Tibang, Balang/Balleh ridge, Kapit District, 915 m [3000 ft], 8 July 1969. - BRuneI. Coode 7592 (K), Temburong, Gunung Pagon, 1480 m, 1 April 1993. - EAST Kalimantan. Geesink 9120 (E, L), between Long Bawan and Panado, 1800 m, 19 July 1981.

Group two - SARAWAK. Burtt \& Martin B5074 (E), SE end of Hose Mt, hillside west of Ulu Melinau falls, 1220 m [4000 ft], 23 Aug. 1967; Burtt \& Martin B5375 (E), route from Bakelalan to Gunung Murud below camp 4, 1830 m [6000 ft], 4 Oct. 1967; Nielsen 880 (E), S slope of W ridge of Mulu, upper tributaries to Sungei Tapin, 1700-1800 m, 26 March 1978.

\section{Cyrtandra iliasii B.L. Burtt - Map 3}

Cyrtandra iliasii B.L. Burtt (1990) 219. - Type: Burtt \& Martin B5012 (holo E; iso SAR n.v.), Sarawak, 7th Div., SE end Hose Mts, above Ulu Melinau Falls, c. 1220 m [4000 ft], 20 Aug. 1967.

Small epiphyte or plant with a tendency to climb, stem woody, bark with a tendency to become flaky near the top of the stem, when young with rough hairs, older growth glabrous. Leaves markedly anisophyllous: major leaf with a hairy, often bryophyte covered $1-1.5 \mathrm{~cm}$ petiole, lamina lorate, $13-17$ by $2-2.8 \mathrm{~cm}$, base asymmetric, shorter side acute, longer side rounded, margins more or less entire, apex acuminate c. $1 \mathrm{~cm}$, upper surface glabrous, often encrusted with bryophytes, lower surface with scattered rough hairs, these often breaking off leaving the base, midrib and lateral nerve pairs covered with rough hairs, lateral nerve pairs 9 or 10 , connected by a skirting vein c. 2 
$\mathrm{mm}$ from the margins; minor leaf sessile, $1-1.2$ by $0.5-0.7 \mathrm{~cm}$, the lower half appressed to and sheathing the stem, the upper half deflexed, margins entire, apex acuminate, lower surface thickened at the base and along the midrib, with rough hairs especially along the midrib, upper surface glabrous. Inflorescence axillary, more or less sessile. Bracts ovate, c. $1 \mathrm{~cm}$, outer and inner surfaces hairy. Bracteoles slightly smaller. Pedicels c. $2 \mathrm{~mm}$ long. Calyx fused upper lobe c. 10 by $4.5 \mathrm{~mm}$, narrowly elliptic, divided into three narrowly triangular thickened points, $2.5-3 \mathrm{~mm}$ long, lower lobes c. 10 by $2 \mathrm{~mm}$, very narrowly ovate, outer surface with quite rough hairs, these shorter at the tips, inner surface glabrous and gland-dotted. Corolla white with an orange mark on the mouth that becomes purple in the throat, c. $13 \mathrm{~mm}$ long (lobes not seen intact), outer surface with hairs on the back of the lobes, inner surface not seen. Filaments not seen (coll. notes 'with red glandular hairs'). Anthers not seen. Gynoecium immature, ovary glabrous, style with glandular hairs. Disk c. $1 \mathrm{~mm}$ long, margin undulate. Fruit not seen.

Distribution - Sarawak (Hose Mts).

Habitat - Altitude c. 1220 m [4000 ft]. Lower montane forest.

Etymology - Named after Ilias bin Paie, of the Sarawak Forest Department.

Note - Cyrtandra iliasii is closely related to C. rubropicta. Close examination of two specimens (Paie S41186, Burtt B12751), cited under the protologue of C. iliasii, has determined them to be $C$. rubropicta, so $C$. iliasii is now only known from the type specimen. This specimen differs in a few characters from C. rubropicta: the leaves are lorate rather than very narrowly obovate; the leaf margins appear to be entire rather than serrate; the lower leaf surface has scattered rough hairs especially on the venation, as opposed to the glabrous lower leaf surface of C. rubropicta, and the corolla is described as being white with an orange mark in the mouth, purple downwards, rather than pink with a red mark in the throat. It therefore was felt that there was not enough evidence to reduce $C$. iliasii to synonymy, despite the similarity in all other features of the inflorescence, especially the calyx. Neither the fruit nor the androecium were seen.

\section{Cyrtandra impar Kraenzl. - Map 5}

Cyrtandra impar Kraenzl. (1927) 97. - Type: Winkler 1070 (holo HBG n.v.; iso E), W Kalimantan, Bukit Bidang Menabai, 700 m, 26 Dec. 1924.

Shrub to $1 \mathrm{~m}$, stem a little branched from the more or less creeping base, bark tessellate. Leaves markedly anisophyllous: major leaf with a short $0.5-1 \mathrm{~cm}$ flaky barked petiole, lamina very narrowly obovate, $17-29$ by $5-13 \mathrm{~cm}$, base decurrent, sometimes slightly asymmetrically so, on smaller leaves the margins of the upper three quarters serrate, serrations upward pointing and up to $2 \mathrm{~mm}$ long, on larger leaves the margins of the upper third serrate, serrations more shallow, up to $1 \mathrm{~mm}$ long, apex acuminate $0.5-2 \mathrm{~cm}$, upper surface glabrous, lower surface glabrous with a prominent midrib and slightly less prominent lateral nerve pairs, lateral nerve pairs 10-16; minor leaf sessile, the lower part appressed to and sheathing the stem and upper part becoming deflexed, or remaining erect and more stipuliform, when deflexed, the lamina $3-3.5$ by $1.2-1.8$ $\mathrm{cm}$, base appressed to the stem, apex acuminate, c. $1 \mathrm{~cm}$, when erect lamina $2-3$ by c. $1.5 \mathrm{~cm}$, base somewhat auriculate either side of the thickened, almost corky base of the midrib, apex acute; margins of both forms with slight serrations, upper and lower 
surfaces of both forms glabrous. Inflorescence axillary, more or less sessile. Bracts ovate, 1-1.8 cm long, margins sometimes slightly serrate, outer surface warty around the base, minutely gland-dotted, inner surface minutely gland-dotted with a tuft of silky hair at the base. Bracteoles numerous, the same size or slightly smaller than the outer bracts, outer surface minutely gland-dotted, inner surface minutely gland-dotted with a tuft of silky hair at the base. Pedicels c. $3 \mathrm{~mm}$ long. Calyx fused upper lobe 10-12 by 6-7 mm, narrowly obovate, divided into three rounded tips, each c. $2 \mathrm{~mm}$ long with a short thickened point at the very top, lower lobes $9-12$ by $3 \mathrm{~mm}$, apex rounded with a short thickened point at the very tip, outer surface minutely gland-dotted, sometimes with short hairs near the apex, inner surface minutely gland-dotted with silky hair at the base. Corolla white or cream with a pale yellow palate, c. $16 \mathrm{~mm}$ long, tube c. 11 $\mathrm{mm}$ long, upper lobes c. 5 by $5.5 \mathrm{~mm}$ with a $2 \mathrm{~mm}$ central sinus, lower lobes c. 5 by $6 \mathrm{~mm}$, more spreading, corolla wall bulging outwards immediately behind the upper lobes resulting in an internal hollow in front of which the anthers lie, outer surface glabrous, inner surface glabrous except for red glandular hairs in the bulge on the roof of the tube. Filaments c. $7 \mathrm{~mm}$ long, with sessile glands on the upper half below the anthers, the connective fringed with a few red glandular hairs. Anthers c. $3 \mathrm{~mm}$ long. Gynoecium c. $12 \mathrm{~mm}$ long (immature), ovary glabrous, style with glandular hairs. Disk c. $2 \mathrm{~mm}$ long, margin undulate. Fruit immature, c. 8 by $4.5 \mathrm{~cm}$, warty.

Distribution - W Kalimantan and W Sarawak (Poi range), represented by only a few collections.

Habitat - Altitude 550-1065 m. Lowland to lower montane forest.

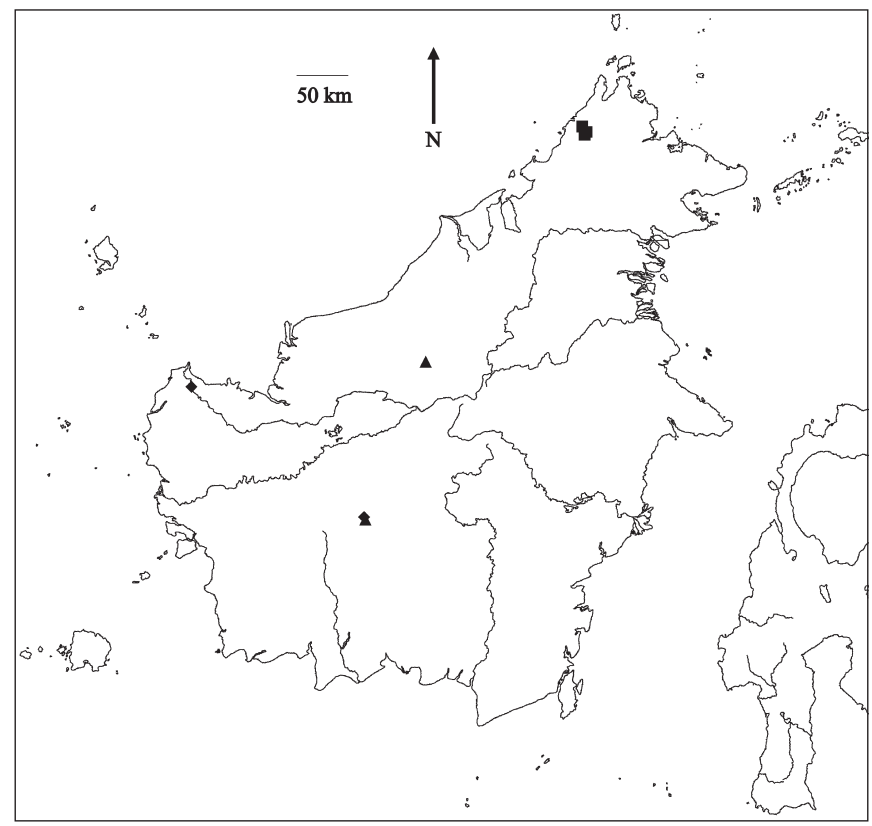

Map 5. Map of Borneo showing the distribution of C. impar Kraenzl. ( $\$$ ); C. rubropicta Kraenzl. (А); C. weberi B.L. Burtt (ם). 
Etymology - The epithet 'impar' means unequal and refers to the anisophyllous leaf pairs.

Note - Cyrtandra impar is one of a group of four closely allied species, the other three members of the group being C. rubropicta, $C$. iliasii and C. bryophila. The group is characterised by its serrate leaf margins, and three of the species show a tendency for roughened bark. However, $C$. impar is distinctive because of its tessellate bark, which is much more flaky than that of the other two species. It shares its white corolla with yellow palate with $C$. bryophila and $C$. iliasii, rather than the pink marked with red corolla of C. rubropicta. Cyrtandra impar is also distinct from C. rubropicta because of the absence of red colouring of the underside of the leaves and the calyx. Each species has a different calyx shape (Fig. 1). Cyrtandra impar has a typically shrubby habit compared to the epiphytic or scrambling herbs C. rubropicta, C. iliasii and C. bryophila.

The specimens seen are slightly variable: Burtt \& Woods $B 2811$ has a deflexed minor leaf and its major leaves are smaller in stature with margins that are more distinctly serrate. The type specimen (Winkler 1070) and Church et al. 1891 have much larger major leaves, the margins of which are less distinctly serrate, and the minor leaf is more stipuliform, remaining erect.

\section{Cyrtandra multibracteata C.B. Clarke - Map 6}

Cyrtandra multibracteata C.B. Clarke (1883) 253. - Type: Beccari 3777 (holo FI n.v., [photo E]), Sarawak, Belaga.

Shrub to $2.5 \mathrm{~m}$, stem woody, bark striate, new growth occasionally a little hairy, becoming glabrescent, sometimes a few hairs remaining in the leaf axils. Leaves markedly anisophyllous: major leaf with a petiole $1-3.5 \mathrm{~cm}$ long, lamina asymmetric, very narrowly to narrowly obovate or narrowly elliptic to elliptic, $16-33$ by $5-17.5 \mathrm{~cm}$, base asymmetric, the shorter side narrowing towards the petiole and more acute than the more rounded longer side, margins more or less entire, apex usually shortly acuminate, sometimes more distinctly acuminate, but extending no more than $1.5 \mathrm{~cm}$, upper surface glabrous, lower surface more or less glabrous with minute bumps almost visible to the naked eye, lateral nerve pairs 6-8(-9) or 8-11; minor leaf either sessile or petiolate; when sessile, either lamina $1.5-4$ by $0.3-1.5 \mathrm{~cm}$, stipuliform, upright, linear or narrowly ovate, the lower half to three quarters appressed to and partially sheathing the stem and the upper part deflexed, or lamina $1.5-4$ by $1.5-3 \mathrm{~cm}$, ovate, the lower third to half almost completely sheathing the stem and the upper part deflexed, in both cases the apex acuminate and margins entire, the lower surface warty around the thickened midrib and base, the upper surface glabrous; when petiolate, lamina 3-4 by $1-2 \mathrm{~cm}$, elliptic, apex and base acute, margins entire, upper and lower surfaces glabrous, lateral nerve pairs c. 4 , petiole to $0.5 \mathrm{~cm}$ long. Inflorescence axillary, very shortly pedunculate. Peduncles less than $5 \mathrm{~mm}$ long, stout. Bracts ovate to narrowly ovate, 1-3 cm long, leathery, thickened at the midrib, partly enclosing the inflorescence, keel-shaped or flattened, base thickened, apex acute or rounded, outer surface glabrous or sometimes with scattered hairs, base warty, inner surface with a tuft of hair at the base, often warty. Bracteoles smaller, narrower, numerous. Pedicels 2-3 mm long, stout. Calyx fleshy, the fused upper lobe $12-15$ by $6-7 \mathrm{~mm}$, elliptic to narrowly obovate, divided into three tips, each $0.5-1.5 \mathrm{~mm}$ long, bluntly triangular with a small thickened point at the very top, lower two lobes $12-13$ by $2.5-4 \mathrm{~mm}$, very narrowly obovate, apex somewhat rounded 
but thickened with a small point at the very tip, outer surface glabrous except for a few short hairs on the thickened tips, inner surface covered with small glands. Corolla white, sometimes with a pink or purplish tint, throat sometimes marked with yellow or purple, 17-18 $\mathrm{mm}$ long, tube $13-14 \mathrm{~mm}$ long, upper lobes $3-5$ by $3-5 \mathrm{~mm}$, with a c. $1 \mathrm{~mm}$ central sinus, lower lobes $4-5$ by $4-5.5 \mathrm{~mm}$, corolla wall bulging outwards immediately behind the lobes resulting in an internal hollow in front of which the anthers lie, outer surface glabrous, inner surface with glandular hairs in the throat, especially within the pouch in the roof of the tube, otherwise glabrous. Filaments with scattered short glandular hairs also occurring along the connectives. Anthers $1.5-2 \mathrm{~mm}$ long. Gynoecium 12-14 mm long, ovary glabrous, style with glandular hairs. Disk c. $1.5 \mathrm{~mm}$ long, margin undulate. Fruit $1-1.5$ by $0.3-0.5 \mathrm{~cm}$, conical, surface papillose/verrucose or smooth, calyx often persisting in fruit.

Distribution - Sarawak, Kalimantan (central and from one location in East Kalimantan).

Etymology - The bracts in this species are numerous and their thick, leathery texture makes them quite distinctive, hence the epithet 'multibracteata'.

Habitat - Altitude 50-1500 m. Lowland to lower montane forest, commonly found growing on rocks in the middle of streams.

Notes - Cyrtandra multibracteata is a very variable species, especially in its leaf morphology, both of the minor and major leaves. It is distributed across Sarawak and has been collected from a handful of locations in Central and East Kalimantan, showing an apparently disjunct distribution, although this is perhaps due to the under-collection of the Kalimantan flora.

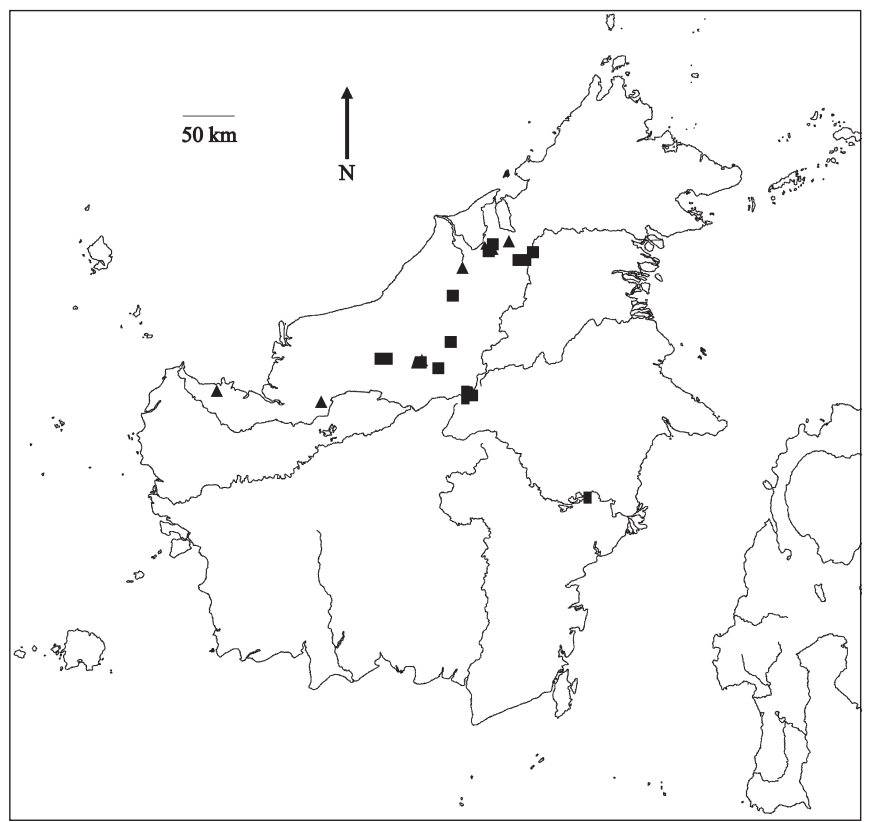

Map 6. Map of Borneo showing the distribution of C. multibracteata C.B. Clarke: group one specimens $(\mathbf{\square})$; group two specimens $(\boldsymbol{\Delta})$. 
Within the morphologically variable $C$. multibracteata, it is possible to recognise two groups of specimens. However, the characters associated with these groups are not wholly diagnostic, making only an informal distinction between the two groups possible. Nevertheless, to highlight the variation within $C$. multibracteata, specimens have been informally placed in either group one or group two (see identification list), the characteristics of which are explained below. The division of the specimens into groups shows that there is no geographical patterning associated with the morphological variation.

Group one represents $C$. multibracteata as exemplified by the type specimen. The plants are substantial in all parts - the leaves are typically elliptic or narrowly obovate, but occasionally narrowly elliptic or very narrowly obovate, $16-33$ by $6-17.5 \mathrm{~cm}$; the bracts are $1.5-3 \mathrm{~cm}$ long. Within this group there is variation in the minor leaf morphology: sometimes the minor leaf sheaths the whole of the axil, a character that is very distinctive in the herbarium, but is not consistent as specimens occur with both leaf types, e.g. Kudi S23843. Burtt B5173 is an anomaly as it has an abnormal calyx with a wider shape more like $C$. fulvisericea, but it is glabrous rather than silky hairy.

Group two represents a large number of specimens that are smaller in stature than the type specimen; they generally have shorter, narrower leaves, $16-24$ by $5-8 \mathrm{~cm}$; smaller bracts $1-1.2$ by $0.6-1 \mathrm{~cm}$; fewer lateral nerve pairs, $6-8$, but share the other inflorescence characters, for example calyx and corolla morphology, with group one.

\section{Cyrtandra rubropicta Kraenzl. - Map 5}

Cyrtandra rubropicta Kraenzl. (1927) 98. - Type: Winkler 783 (holo HBG n.v.), W Kalimantan, Schwaner Gorge, Bukit Bidang Menabai, 700-1370 m [4500 ft], 12 Dec. 1924.

Epiphyte or scrambler, epiphytic up to c. $9 \mathrm{~m}$; stem woody, bark rough, almost becoming flaky, when young with some hair around the petioles and axils. Leaves markedly anisophyllous: major leaf with a short, stout, $0.5-1 \mathrm{~cm}$ petiole, lamina very narrowly obovate, $13-21$ by $4-6.5 \mathrm{~cm}$, base acute, sometimes slightly asymmetrical, margins serrate in the upper three quarters of the lamina, serrations pointing upward at c. $45^{\circ}$, up to $2 \mathrm{~mm}$ deep with obtuse tips, apex acuminate, c. $1.5 \mathrm{~cm}$, upper surface with some hairs at the base of the midrib when young, otherwise glabrous, lower surface glabrous, the midrib and lateral nerve pairs prominently raised, lateral nerve pairs $12-14$, connected by a skirting vein $2-3 \mathrm{~mm}$ from the margins; minor leaf sessile, often caducous, lamina $1.5-2$ by $0.5-1.5 \mathrm{~cm}$, either lower half sheathing and remaining pressed to the stem, upper part deflexed, or base not so appressed to the stem, upper part not deflexed, in both cases margins sometimes slightly serrate, upper and lower surfaces glabrous, midrib thickened near the base. Inflorescence axillary, more or less sessile. Bracts ovate, $12-13$ by $9 \mathrm{~mm}$, quite fleshy, margins undulate, outer surface gland-dotted, with scattered short hairs especially concentrated along the midrib, warty at the base, inner surface gland-dotted, with long appressed hairs at the base and much shorter upward pointing hairs covering the remaining surface. Bracteoles narrowly ovate, $9-11$ by 3-6 $\mathrm{mm}$, both outer and inner surfaces gland-dotted and with short hairs, the inner surface with a tuft of longer hair at the base. Pedicels c. $2 \mathrm{~mm}$ long. Calyx bright red, fused upper lobe $10-11$ by $3.5-4.5 \mathrm{~mm}$, very narrowly ovate or narrowly elliptic, divided into three very narrowly triangular tips, each 1.5-2 mm long, thickened, lower lobes 
$7-10$ by $2 \mathrm{~mm}$, very narrowly ovate, outer surface with appressed delicate hairs, these slightly shorter at the calyx tips, inner surface with gland dots. Corolla pink with red marks on the lower surface of the tube, c. $15 \mathrm{~mm}$ long, tube c. $11 \mathrm{~mm}$ long, upper lobes c. 3 by $3.5 \mathrm{~mm}$ with a c. $1.5 \mathrm{~mm}$ central sinus, lower lobes c. 4 by $4.5 \mathrm{~mm}$, outer surface with short hairs on the back of the lobes, inner surface with a few glandular hairs in the roof of the tube at the base of the upper lobes, otherwise glabrous. Filaments with sessile glands on the upper half and a few glandular hairs on the connectives. Anthers c. $1.5 \mathrm{~mm}$ long. Gynoecium immature, ovary glabrous, style with glandular hairs and some longer eglandular hairs near the top of the developing ovary. Disk c. $1.5 \mathrm{~mm}$ long, undulate. Fruit 9 by $7 \mathrm{~mm}$, ovate, warty.

Distribution - Sarawak (Hose Mts), extending south into W Kalimantan.

Habitat - Altitude: only recorded at c. 1370 m [4500 ft]. Epiphytic in lower montane forest.

Etymology - The epithet 'rubropicta' refers to the plant's red colouring, often noted to occur on the calyx, corolla and the underside of the leaves.

Note - Cyrtandra rubropicta is distinctive, like C. impar, because of its tendency for roughened to flaky bark and serrate leaf margins. However, the bark of C. rubropicta is much less flaky, and often only roughened, unlike the tessellate bark of $C$. impar. It differs further from $C$. impar in its hairy rather than glabrous or sparsely hairy bracts and calyx and in the shape of its calyx lobes, especially that of the upper. In addition it is reported to have an epiphytic habit rather than the shrubby habit of $C$. impar, and the corolla is pink marked with red and hairy in parts, unlike the white corolla of C. impar which is marked with yellow and glabrous. Furthermore, as its name suggests, C. rubropicta has red colouring on the underside of the leaves and on the calyx.

\section{Cyrtandra stonei B.L. Burtt - Map 2}

Cyrtandra stonei B.L. Burtt (1990) 229. - Cyrtandra dispar A.DC. var. glabriflora B.C. Stone (1980) 262. - Type: Stone 14051 (holo KLU; iso K, KEP, L), Malay Peninsula, Pahang, Ulu Kali, path to Gunung Lari Tembakau, 1600 m [5200 ft], 18 March 1979.

Subshrub, 1-1.5 m tall, stem quadrangular, fleshy, glabrous, the lower part becoming woody. Leaves markedly anisophyllous: major leaf with a petiole $3-4 \mathrm{~cm}$ long, lamina asymmetrically narrowly elliptic to very narrowly ovate, $15-22$ by $5-7 \mathrm{~cm}$, base asymmetric with one side of the lamina narrowing towards the petiole before the other, the wider side acute and often up to 1-2 cm longer, margins very shallowly dentate, apex acuminate, upper and lower surfaces glabrous, lateral nerve pairs 9-12; minor leaf sessile or with a petiole less than $5 \mathrm{~mm}$ long, lamina narrowly to very narrowly ovate, 4-6 by $1.5-2 \mathrm{~cm}$, margins very slightly dentate, apex acute, upper and lower surfaces glabrous. Inflorescence axillary, more or less sessile, up to 8-flowered. Bracts 1-2 cm long, narrowly to very narrowly ovate, enclosing inflorescence. Bracteoles smaller and narrower. Pedicels c. $1 \mathrm{~cm}$ long. Calyx white, fused upper lobe c. 11 by 6 $\mathrm{mm}$, narrowly ovate, divided into three distinct acuminate tips, each $1.5-2 \mathrm{~mm}$ long, thickened, this thickening extending to form slightly raised ridges down the lobe, outer surface with papillae scattered across the ridges, inner surface with scattered papillae, lower lobes c. 10 by $4 \mathrm{~mm}$, narrowly ovate, outer surface glabrous, inner surface with scattered papillae. Corolla white, somewhat translucent, with a yellow mark in the 
throat, c. $17 \mathrm{~mm}$ long, tube narrow at base, then constricted further at c. $5 \mathrm{~mm}$ before broadening, tube c. $13 \mathrm{~mm}$ long, all lobes $3.5-4$ by $3.5-4 \mathrm{~mm}$, outer surface glabrous, inner surface with papillae below the upper two lobes and in the throat. Filaments c. $5 \mathrm{~mm}$ long, with glandular hairs, these also occurring along the connectives. Anthers c. $1 \mathrm{~mm}$ long. Gynoecium c. $1 \mathrm{~cm}$ long, ovary glabrous, style with glandular hairs. Disk c. $2 \mathrm{~mm}$ long, margin uneven. Fruit green, $1.2-1.5$ by $0.9 \mathrm{~cm}$, ovate to globose, fleshy, with a short c. $2 \mathrm{~mm}$ apiculus remaining from the otherwise caducous style, calyx semi-persistent.

Distribution - Peninsular Malaysia (Genting Highlands).

Habitat - Altitude $1600 \mathrm{~m}$. Upper montane forest, often in open and secondary vegetation.

Etymology - Named in honour of B.C. Stone (1933-1994), a distinguished botanist working for many years at KLU.

Notes - Cyrtandra stonei is the only Peninsular Malaysian representative of section Dissimiles C.B. Clarke, and is endemic to the Genting Highlands. It is allied to the two Sumatran members of the section, $C$. anisophylla and $C$. beccarii, sharing bract and calyx morphology with $C$. beccarii, and a sessile inflorescence with $C$. anisophylla. It could be suggested that $C$. stonei is the result of the dispersal from Sumatra to Peninsular Malaysia of $C$. anisophylla or $C$. beccarii (with subsequent evolution), an event that is plausible since periods of lower sea levels in history exposed land between Sumatra and the Malay Peninsula (Voris, 2000). There are a number of western Peninsular Malaysian species that have a close affinity to Sumatran species, and some species, for example $C$. dispar DC., have a distribution spanning both countries.

Cyrtandra stone $i$ has a narrow distribution and has not been widely collected. In the field the quadrangular stem is noticeable, as well as the glabrous leaves and the small, quite translucent, white corolla, which has a bright yellow throat.

Cyrtandra stonei grows in areas quite unlike other Cyrtandra species, which inhabit damp and fairly dark areas in the rain forest. It was found at high altitude, growing along the roadside in open vegetation, which included Musa spec. and Dicranopteris linearis Burm.f.

\section{Cyrtandra trisepala C.B. Clarke - Map 7}

Cyrtandra trisepala C.B. Clarke (1883) 253. - Type: Beccari 2452 (holo FI n.v., [photo E]; iso K) Sarawak, Gunung Gading, Dec. 1866.

Cyrtandra producta Kraenzl. (1927) 95. - Type: Winkler 968 (lecto, chosen here, HBG [photo]; isolecto E), Kalimantan, Bukit Raya [Raja].

Small shrub or epiphyte to c. $2.5 \mathrm{~m}$, stem woody, bark pale, striate, young growth sometimes with hairs especially in the axils, older growth glabrous. Leaves very occasionally occurring in more or less equal pairs, most often pairs markedly anisophyllous: major leaf with a more or less glabrous petiole 1-1.5 cm long (much darker in colour than the main stem on drying), lamina narrowly elliptic to very narrowly obovate, 12-19 by $3-7 \mathrm{~cm}$, base asymmetric, one side shorter and acute, the longer side more rounded, margins entire, apex acuminate 1-1.5 cm, upper surface glabrous, lower surface with scattered appressed hairs or occasionally glabrous, minutely bumpy, lateral nerve pairs 8 or $9(10-12,14-17)$; minor leaf sessile $0.8-1.5(-2)$ by $0.2-0.5 \mathrm{~cm}$, very narrowly ovate, stipuliform, chartaceous, thickened at the midrib and the base, margins entire, 
apex erect, outer surface warty with some hairs, inner surface with a tuft of hair at the base. Inflorescence axillary, very shortly pedunculate. Peduncle $0.5-3 \mathrm{~mm}$ long. Bracts $0.8-1.3$ by $0.3-0.4 \mathrm{~cm}$, very narrowly ovate, similar to the minor leaf, chartaceous, outer surface more or less glabrous or occasionally with scattered hairs, inner surface with a tuft of hair at the base. Bracteoles slightly longer and wider, numerous. Pedicels up to $1 \mathrm{~mm}$ long. Calyx fused upper lobes $9-12$ by 3-6 mm, very narrowly to narrowly obovate, divided into three rounded tips c. $1 \mathrm{~mm}$ long, non-thickened, margins entire or occasionally irregularly dentate in the upper half, lower lobes $8-10$ by $2-3$ $\mathrm{mm}$, very narrowly obovate to almost lorate, apex rounded and non-thickened, margins entire, outer surface glabrous or with very few hairs at the tips, inner surface somewhat granular in texture. Corolla white with a greenish or pink to purple tinge, 14-17 mm long; tube $11-13 \mathrm{~mm}$ long, upper lobes $2.5-3$ by $4 \mathrm{~mm}$ with a c. $1.5 \mathrm{~mm}$ central sinus, lower lobes $3-4$ by $5-6 \mathrm{~mm}$, the corolla wall bulging outwards immediately behind the upper lobes resulting in an internal hollow in front of which the anthers lie, outer surface with short hairs on the back of the lobes, inner surface glabrous except for the hollow which is filled with glandular hairs. Filaments c. $5 \mathrm{~mm}$ long, with glandular hairs that also occur along the connective margins. Anthers c. $1.5 \mathrm{~mm}$ long. Gynoecium c. $9 \mathrm{~mm}$ long (immature), ovary glabrous, style with glandular hairs. Disk $2 \mathrm{~mm}$ long, margins undulate. Fruit $1.2-1.3$ by $0.3-0.5 \mathrm{~cm}$, narrowly ovate, verrucose, sometimes scarcely so.

Distribution - W Sarawak and Kalimantan, extending into Central Sarawak.

Habitat - Altitude 50-500 m. Lowland forest, often near streams or on rocks in the streambed.

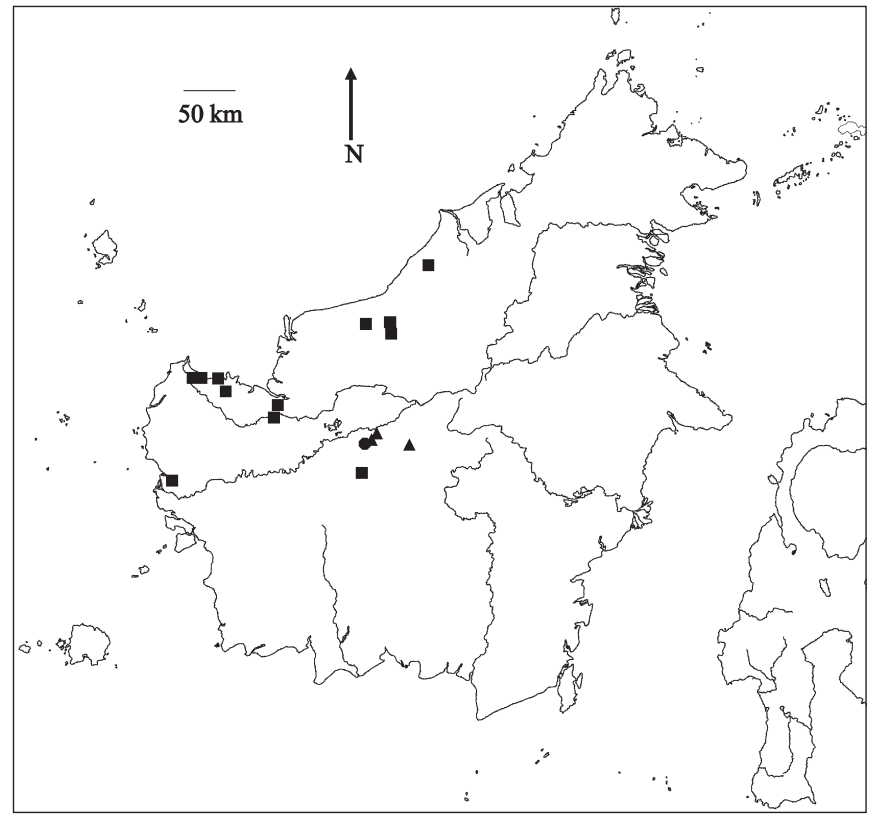

Map 7. Map of Borneo showing the distribution of C. trisepala C.B. Clarke: group one specimens $(\mathbb{\square})$; group two specimens $(\bullet)$; group three specimens $(\mathbf{\Delta})$. 
Etymology - The epithet 'trisepala' refers to the distinctive zygomorphic calyx of this species, which is characteristic of section Dissimiles, in which the upper three lobes are fused and the lower two separated to the base, resulting in a three lobed calyx rather than the typical five lobed calyx usually found in Cyrtandra.

Notes - Cyrtandra trisepala is most recognisable by its rather delicate, very narrowly ovate minor leaf, the tip of which remains erect, and its calyx, which is also quite delicate, and has an upper lobe with three rounded non-thickened tips.

Cyrtandra trisepala is a variable species, differing especially in the degree of hairiness of the leaves, in the number of lateral nerve pairs and in the entirety of the calyx margins: it is possible to divide most of the specimens into three groups, representing the extremes of this morphological variation. However, the characters defining the groups are not wholly diagnostic since the variation is to some extent continuous, and they do not correlate with other factors such as geography. Formal recognition of the groups is therefore not possible. Nevertheless, to highlight the variation and to ease identification, the specimens are cited under these informal groups in the identification list. A short description of each group follows.

Group one: specimens in this group can be more or less completely glabrous, but it is also common to find some hairs on the new growth and the lower surfaces of more mature leaves. The upper lobe of the calyx has three rounded, non-thickened tips, and is generally quite narrow with entire margins. The habit of Webb CW3644 differs from the other specimens, being a treelet to $5 \mathrm{~cm}$ dbh, rather than a shrub of up to $2.5 \mathrm{~m}$ in height. Furthermore, George S38284 has 11 or 12 lateral nerve pairs rather than 8 or 9, the typical number for group one, and its new growth and lower leaf surfaces are more hairy than on the other specimens in the group.

Group two: this group contains just one specimen, Church et al. 2288. It is distinct in being a woody scrambler to $4 \mathrm{~m}$, its leaves are very narrowly obovate with an unusual slightly dentate margin in the upper third, and it has a much greater number of lateral nerve pairs (14-17).

Group three: specimens in group three differ from those in groups one and two by the combination of greater hairiness, generally more lateral nerve pairs (10-12), usually irregularly dentate calyx margins and greater hairiness of the outside of the corolla lobes (although flowers have only been seen in bud). The specimens in this group represent C. producta (synonymised here), and include Kraenzlin's type specimen and similar collections from near the type location: Jarvie et al. 5869, Burley et al. 824 (although this collection differs in its calyx, which has entire margins, and a longer upper lobe, c. 12 by 3.5 vs $7-9$ by $3-4 \mathrm{~mm})$.

Cyrtandra producta is synonymised here. Winkler 968 has been chosen as its lectotype from the syntypes Kraenzlin gives under the $C$. producta protologue. This specimen and Jarvie et al. 5869 (see group three) seem conspecific, differing from C. trisepala s.s. by the greater hairiness of the leaves and parts of the inflorescence, and the margins of the calyx that are irregularly dentate rather than entire. However, one specimen from the type area, Burley et al. 824 , shares the greater hairiness of the leaves and parts of the inflorescence but has a calyx with entire margins as found in C. trisepala s.s. In addition, there are specimens from groups one and two in the type area (e.g. group two: Church et al. 2288) making the boundary between C. producta and $C$. trisepala blurred and unjustifiable. 


\section{Cyrtandra weberi B.L. Burtt - Map 5}

Cyrtandra weberi B.L. Burtt (1990) 232. - Type: Weber 790921-1/6 (holo WU), Sabah, Mt Kinabalu, Kiau view trail, 1100 m, 21 Sept. 1979.

Woody herb or shrublet, to c. $1.2 \mathrm{~m}$ (4 ft), stem somewhat fleshy when young, becoming woody, bark increasingly striate with age, glabrous. Leaves markedly anisophyllous: major leaf with a petiole $1-5.5 \mathrm{~cm}$ long, lamina narrowly elliptic, $8.5-21$ by $3.5-8.5$ $\mathrm{cm}$, base usually asymmetric, the shorter side acute to rounded, the longer side most often rounded but more acute when the base is less distinctly asymmetric, margins serrate, serrations quite widely spaced, very slight or up to $2 \mathrm{~mm}$ deep, tips obtuse, apex shortly acuminate, when young upper surface with scattered short quite rough hairs, a few hairs remaining on older leaves, lower surface with short quite rough hairs on the midrib and primary nerve pairs, lateral nerve pairs 8-10; minor leaf sessile or with a petiole less than $5 \mathrm{~mm}$ long, lamina narrowly ovate, $1.5-8$ by $0.6-3.5 \mathrm{~cm}$ (size proportional to size of major leaf), base thickened around the midrib, margins serrate, serrations less conspicuous than those on the major leaf, apex acute to shortly acuminate, upper and lower surfaces glabrous, lateral nerve pairs up to 5 or 6 . Inflorescence axillary, shortly pedunculate. Peduncle $2-5 \mathrm{~mm}$ long. Bracts ovate, 14-20 by $14-18 \mathrm{~mm}$, margins sometimes a little undulate, outer and inner surface glabrous. Bracteoles shorter and narrower. Pedicels 3-5 mm long, extending to $1 \mathrm{~cm}$ as fruit matures. Calyx fused upper lobe $17-19$ by $15-17 \mathrm{~mm}$, broadly obovate, divided into three broad rounded tips $3-5$ by $3-6 \mathrm{~mm}$, delicate and non-thickened, lower lobes divided to the base $15-17$ by $6-8 \mathrm{~mm}$, very narrowly obovate, apex rounded, outer surface glabrous, inner surface with an even covering of sessile glands. Corolla white, with a yellow or orange mark in the throat, up to $3 \mathrm{~cm}$ long (lobes not seen intact), outer surface glabrous, inner surface with glandular hairs densely covering the upper and lower throat but not extending onto the lobes. Filaments c. $12 \mathrm{~mm}$ long (mature but not yet dehisced), with scattered glandular hairs, these more densely covering the connectives. Anthers c. $3 \mathrm{~mm}$ long. Gynoecium c. $16 \mathrm{~mm}$ long (immature), ovary glabrous, style with scattered glandular hairs. Disk 1-1.5 mm long, margin undulate. Fruit $1-1.2$ by $0.6-0.7 \mathrm{~cm}$, ovate, glabrous.

Distribution - Restricted to Mt Kinabalu, Sabah.

Habitat - Altitude 1100-2895 m. Lower to upper montane forest.

Etymology - Named after Professor Anton Weber of Vienna University, who has contributed much to the understanding of Gesneriaceae.

Note - Cyrtandra weberi is easily distinguishable from the other species of section Dissimiles from Mt Kinabalu (C. fulvisericea) because of its serrate leaf margins and its calyx, which is much larger (17-19 $\mathrm{mm}$ vs 9-12 $\mathrm{mm}$ ) than any of the other species of the section, and in addition has a distinctive upper lobe with an apex that is divided into three non-thickened, broad rounded tips, glabrous and delicate in texture.

Within C. weberi, there is morphological variation: Fuchs 21476, Clemens 33758 and Clemens 35020 are all larger and more substantial and shrubby, with thicker stems and a larger minor leaf, $3.5-8$ by $1.5-3.5 \mathrm{~cm}$, being especially distinctive. $R S N B 4956$, Clemens 32427 and Clemens 33993 are all smaller, more delicate and more herbaceous, with a sessile minor leaf, $1.5-2.5$ by $0.6-1 \mathrm{~cm}$. This variation corresponds to altitudinal differences - the larger specimens were collected between 2440 and $2895 \mathrm{~m}$ and the smaller specimens between 1370 and $1585 \mathrm{~m}$. 


\section{ACKNOWLEDGEMENTS}

The loan of material from the herbaria A, BM, K, KEP, L, SING is gratefully acknowledged. I would like to thank the curators of BM, K, KEP and SING for giving permission to work in their herbaria. I am much obliged to Bill Burtt, Olive Hilliard, Hannah Atkins, Toby Pennington and Quentin Cronk for their advice and comments on the manuscript, to Bill Burtt for advice on the Latin diagnosis, and to Christina Oliver for help with illustrations. This work was funded by a BBSRC PhD studentship. I would also like to acknowledge all the advice, assistance and great encouragement that the late Mary Mendum gave me in support of my work.

\section{REFERENCES}

Atkins, H. \& Q.C.B. Cronk. 2001. The genus Cyrtandra (Gesneriaceae) in Palawan, Philippines. Edinburgh J. Bot. 58: 443-458.

Bramley, G.L.C. 2003. Local, regional and monographic approaches to Cyrtandra (Gesneriaceae). Unpublished $\mathrm{PhD}$ thesis, University of Edinburgh, UK.

Bramley, G.L.C. \& Q.C.B. Cronk. 2003. The Cyrtandra (Gesneriaceae) species of Mount Kerinci, Sumatra. Harvard Pap. Bot. 7: 407-421.

Bramley, G.L.C., R.T. Pennington, R. Zakaria, S.S. Tjitrosoedirdjo \& Q.C.B. Cronk. 2004a. Assembly of tropical plant diversity on a local scale: Cyrtandra (Gesneriaceae) on Mount Kerinci, Sumatra. Biol. J. Linn. Soc. 81: 49-62.

Bramley, G.L.C., A. Weber \& Q.C.B. Cronk. 2004b. The Cyrtandra (Gesneriaceae) species of Peninsular Malaysia and Singapore. Edinburgh J. Bot. 60: 331-360.

Burtt, B.L. 1970. Studies in the Gesneriaceae of the Old World XXXIII: Some species of Cyrtandra, chiefly Bornean. Notes Roy. Bot. Gard. Edinburgh 30: 23-42.

Burtt, B.L. 1978. Studies in the Gesneriaceae of the Old World XLIV. New and little-known species of Cyrtandra, chiefly from Sarawak. Notes Roy. Bot. Gard. Edinburgh 36: 157-179.

Burtt, B.L. 1990. Gesneriaceae of the Old World, I. New and little-known species of Cyrtandra from Malesia. Edinburgh J. Bot. 47: 201-233.

Burtt, B.L. 2001. A survey of the genus Cyrtandra (Gesneriaceae). Phytomorphology, Golden Jubilee Issue: $393-404$.

Clarke, C.B. 1883. Cyrtandreae. In: A. \& C. de Candolle, Monographiae phanerogamarum 5: 1-303, plates 1-32. Masson, Paris.

Forster, J.R. \& J.G.A. Forster. 1775. Characteres generum plantarum 5. London.

Gillett, G.W. 1967. The genus Cyrtandra in Fiji. Contr. US Natl. Herb. 37: 107-159.

Hickey, L.J. 1979. A revised classification of the architecture of dicotyledonous leaves. In: C.R. Metcalfe \& L. Chalk (eds.), Anatomy of the Dicotyledons. Vol. 1 (2nd ed.): 25-39. Oxford University Press, Oxford.

Hillebrand, W. 1888. Gesneriaceae. In: Flora of the Hawaiian Islands. Williams \& Norgate, London, UK and Westermann \& Co., New York, USA.

Hilliard, O.M., B.L. Burtt \& M.H. Bokhari. 2003. Pleuroschisma, a new section of Cyrtandra (Gesneriaceae) from Borneo. Gard. Bull. Singapore 55: 35-60.

Kraenzlin, F. 1927. Beiträge zur Kenntnis der Flora von Borneo 5. Gesneriaceae. Mitt. Inst. Allg. Bot. Hamburg 7: 81-113.

Schlechter, R. 1923. Gesneriaceae papuanae. In: C. Lauterbach, Beitrage zur Flora Papuasien. X. Bot. Jahrb. Syst. 58: 255-379.

St. John, H. 1966. Monograph of Cyrtandra on Oahu. Bernice P. Bishop Mus. Bull. 22: 1-465.

St. John, H. 1987. Diagnoses of Cyrtandra species (Gesneriaceae) section Crotonocalyces. Hawaiian Plant Studies 156. Phytologia 63: 487-493.

Stone, B.C. 1980. Additions to the Malayan Flora 8. Malaysian Forester 43: 244-262.

Voris, H.K. 2000. Maps of Pleistocene sea levels in Southeast Asia: shorelines, river systems and time durations. J. Biogeogr. 27: 1153-1167. 
Wagner, W.L., D.R. Herbst \& S.H. Sohmer. 1990. Manual of the flowering plants of Hawaii. University of Hawaii Press/Bishop Museum Press.

Wagner, W.L., D.R. Herbst \& S.H. Sohmer. 1999. Manual of the flowering plants of Hawaii: 735-781. Revised edition. Bishop Museum, Honolulu.

\section{IDENTIFICATION LIST}
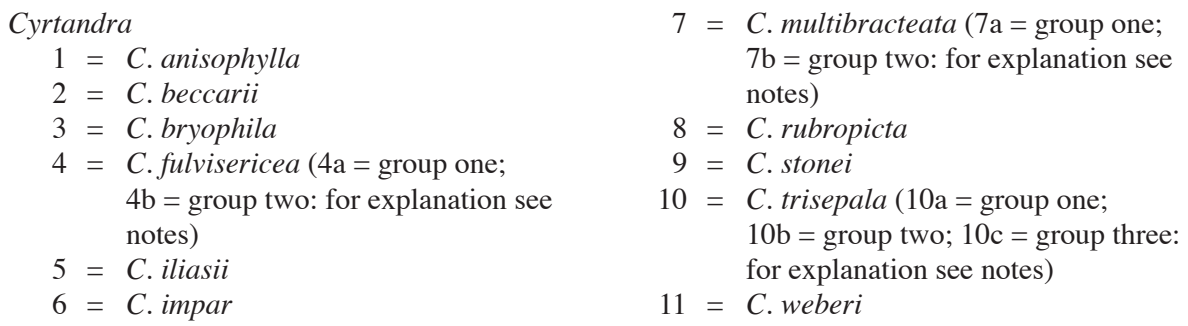

Alston 13972: 1; 14856: 1 - Anderson 31761: 10a; S20972: 7b; S28454: 4a; S28864: 7a - Anderson \& Ilias Paie S28351: 7a; S28677: 4a; S28885: 7a - Argent 1345: 4a - Ashton S19157: 4a - Awa \& Lee S47505: 7b; S47529: 7b - Awa \& Yii S46609: 7b - Awa et al. S50487: 4a.

Beaman \& Beaman 7005: 4a - Beaman et al. 7375: 4a; 9164: 4a; 9165: 4a - Beccari 327 (type): 2; 2452 (type): 10; 3777 (type): 7; s.n. (type): 1 - Bramley et al. GB34: 9 - Bünnemeijer 885: 2; 1123: 2; 8405: 1; 8554: 1;9011: 1; 9585: 1 - Burley et al. 824: 10c - Burtt B11364: 7a; B12751: 8; B12770: 8; B12875: 7a; B12880 (type): 3; B12912: 7b; B12953: aff. 4 - Burtt \& Martin B4801: 7a; B4953: 7b; B5012 (type): 5; B5056: 7b; B5074: 4b; B5168: 4b; B5173: 7a; B5280: 4b; B5375: 4b; B5566: 4b - Burtt \& Woods B2285: 7b; B2595: 7a; B2709: 10a; B2811: 6.

Carr SFN26330: 4a; SFN27589: 4a; SFN27722: 4a - Chai S34020: 7b; S36019: 4a; S36200: 4a - Chai \& Lehmann S30089: 7a - Chua et al. FRI40800: 9; FRI40581: 9 - Church et al. 1891: 6; 2288: 10b; 2354: 8 - Chew Wee-Lek CWL1432: 10a - Chew Wee-Lek et al. 4537: 4a; 4688: 4a; RSNB1431: 4a; RSNB1439: 4a; RSNB2654: 4a; RSNB2813: 4a; RSNB4051: 4a; RSNB4956: 11; RSNB6011: 4a - Clemens 21645: 7b; 26061: 4a; 26253: 4a; 27286: 4a; 28288: 4a; 28810: 4a; 31127: 4a; 31349: 4a; 32402 (type): 4; 32427: 11; 32432: aff. 4; 33758: 11; 33993: 11; 35020: 11 - Coode 7592: 4a - Cronk et al. CBHM4: 4a; CBHM13: 4a; CBHM16: 4a.

Darnton 474: 4a - Davies et al. SJD99046: 4a - De Wilde \& De Wilde-Duyfjes 13511: 2; 18992: 1.

Endert 4578: 4a.

Fuchs 21476: 11 - Fuchs \& Collenette 21395: 4a.

Geesink 9018: 4a; 9120: 4a - George S38284: 10a.

Hirano \& Hotta 509: 7a.

Ilias bin Paie S19255: 10a; S27214: 4a; S28447: 4a; S41186: 8; S42470: 10a.

Jarvie \& Ruskandi 5869: 10c - Jermy 14260: 7b - Jimpin SAN118736: 4a; SAN125568: 4a — Jugah Kudi S23713: 10a; S23843: 7a.

Kiah S3: 4a - Kokawa \& Hotta 4055: 4a; 5775: 4a - Krispinus SAN113852: 4a; SAN128397: $4 \mathrm{a}$.

Laijanai \& Banyeng S37035: 7b — Lee S38067: 7b; S38859: 7a; S43231: 10a; S45509: 7b — Lewis 286: 7a.

Meijer SAN20333: aff. 4 - Mendum \& Lamb 14: 4a; 17: 4a; 18: 4a; 27: 4a - Mohtar S48249: 4a - Mondih 2b: 10a - Murata et al. B1169: 7a - Musi SAN106959: aff. 4.

Nagamasu 3515: 1 - Nielsen 880: 4b - Nooteboom \& Chai 1852: 7a; 1914: aff. 4; 2074: aff. 4; 2309: 7a.

Ohsawa et al. A-176: 1.

Pereira et al. JTP294: 4a - Purseglove P5221: 10a.

Radhiah \& Cronk 109: 1 - Rahmat si Boeea 9591: 1 - Richards 1047: 7a. 
Sinanggul SAN38366: 4a - Smith S27745: 7a - Stevens et al. 610: 4a; 653: 4a - Stone 14051 (type): 9 - Sumbing \& Fidilis SAN125485: 4 a.

Unyong S19639: 7b.

Van Borssum Waalkes 2187: 2.

Webb CW3644: 10a - Weber 790921-1/6 (type): 11 - Weber \& Vogel 790805: 9 - Winkler 783 (type): 8; 968: 10c; 1070 (type): 6.

Yii et al. S51686: 7a; S52069: 7a.

\section{INDEX}

Numbers refer to the species numbers given in the text. Synonyms are in italics. New species are in bold.

Cyrtandra J.R. Forst. \& G. Forst. [p. 166]

sect. Dissimiles C.B. Clarke [p. 166]

anisophylla C.B. Clarke 1

beccarii C.B. Clarke 2

bryophila B.L. Burtt 3

fulvisericea Bramley 4

iliasii B.L. Burtt 5

impar Kraenzl. 6

multibracteata C.B. Clarke 7

producta Kraenzl. 10

rubropicta Kraenzl. 8

stonei B.L. Burtt 9

trisepala C.B. Clarke 10

weberi B.L. Burtt 11 